University of South Florida

DIGITAL COMMONS

Digital Commons @ University of

@ UNIVERSITY OF SOUTH FLORIDA

South Florida

USF Accountability Reports

USF Archives

$1-1-2010$

\title{
2010 Annual Report USF Tampa
}

USF

Follow this and additional works at: https://digitalcommons.usf.edu/usf_accountability_reports

\section{Scholar Commons Citation}

USF, "2010 Annual Report USF Tampa" (2010). USF Accountability Reports. 10.

https://digitalcommons.usf.edu/usf_accountability_reports/10

This Article is brought to you for free and open access by the USF Archives at Digital Commons @ University of South Florida. It has been accepted for inclusion in USF Accountability Reports by an authorized administrator of Digital Commons @ University of South Florida. For more information, please contact digitalcommons@usf.edu. 


\section{University of South Florida--Tampa}

Approved by the USF System BOT, December 16th, 2010 


\begin{tabular}{|c|c|c|c|c|c|c|c|}
\hline \multicolumn{8}{|c|}{ University of South Florida 2010 Annual Report } \\
\hline & & & \multicolumn{5}{|c|}{ USF Tampa } \\
\hline Enrollments & $\#$ & $\%$ & \multicolumn{3}{|c|}{ Degree Programs Offered (As of Spr. 10) } & \multicolumn{2}{|r|}{ Carnegie Classification } \\
\hline $\begin{array}{c}\text { TOTAL } \\
\text { (Fall 2009) }\end{array}$ & 40,267 & $100 \%$ & \multicolumn{2}{|l|}{ TOTAL } & 233 & $\begin{array}{l}\text { Undergraduate } \\
\text { Instructional Program: }\end{array}$ & $\begin{array}{l}\text { Balanced arts \& sciences/professions, high graduate } \\
\text { coexistence }\end{array}$ \\
\hline Black & 4,776 & $12 \%$ & \multicolumn{2}{|c|}{ Baccalaureate } & 92 & \multirow{2}{*}{$\begin{array}{l}\text { Graduate Instructional } \\
\text { Program: }\end{array}$} & \multirow{2}{*}{ Comprehensive doctoral with medical/veterinary } \\
\hline Hispanic & 5,613 & $14 \%$ & \multicolumn{2}{|c|}{ Master's \& Specialist's } & 100 & & \\
\hline White & 25,064 & $62 \%$ & \multicolumn{2}{|c|}{ Research Doctorate } & 38 & Enrollment Profile: & High undergraduate \\
\hline Other & 4,814 & $12 \%$ & \multicolumn{2}{|c|}{ Professional Doctorate } & 3 & Undergraduate Profile: & $\begin{array}{l}\text { Medium full-time four-year, selective, higher transfer } \\
\text { in }\end{array}$ \\
\hline Full-Time & 26,918 & $67 \%$ & \multirow{2}{*}{$\begin{array}{c}\text { Faculty } \\
\text { (Fall 2009) }\end{array}$} & \multirow{2}{*}{$\begin{array}{l}\text { Full- } \\
\text { Time }\end{array}$} & \multirow{2}{*}{ Part-Time } & Size and Setting: & Large four-year, primarily nonresidential \\
\hline Part-Time & 13,349 & $33 \%$ & & & & \multirow{2}{*}{ Basic: } & \multirow{2}{*}{ Research Universities (very high research activity) } \\
\hline Undergraduate & 30,007 & $75 \%$ & TOTAL & 1,424 & 210 & & \\
\hline Graduate & 8,514 & $21 \%$ & Tenure/T. Track & 980 & 78 & \multirow{2}{*}{ Elective Classification: } & \multirow{2}{*}{$\begin{array}{l}\text { Community Engagement: } \\
\text { Outreach \& Partnerships }\end{array}$} \\
\hline Unclassified & 1,746 & $4 \%$ & Other Faculty/Instr. & 444 & 132 & & \\
\hline
\end{tabular}

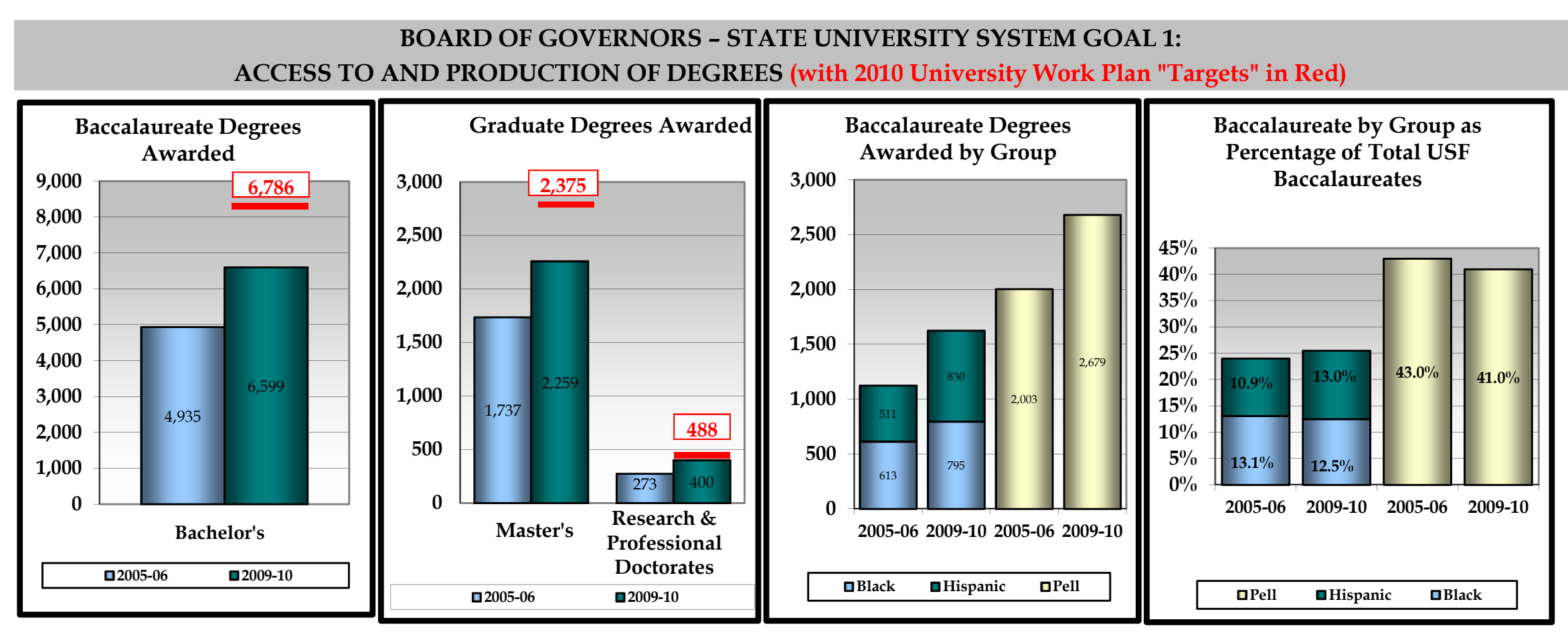

2012 - 2013 Projected Institutional Contributions in RED PRINT. 
BOARD OF GOVERNORS - STATE UNIVERSITY SYSTEM GOAL 2:

MEETING STATEWIDE PROFESSIONAL AND WORKFORCE NEEDS (with 2010 University Work Plan "Targets" in Red)

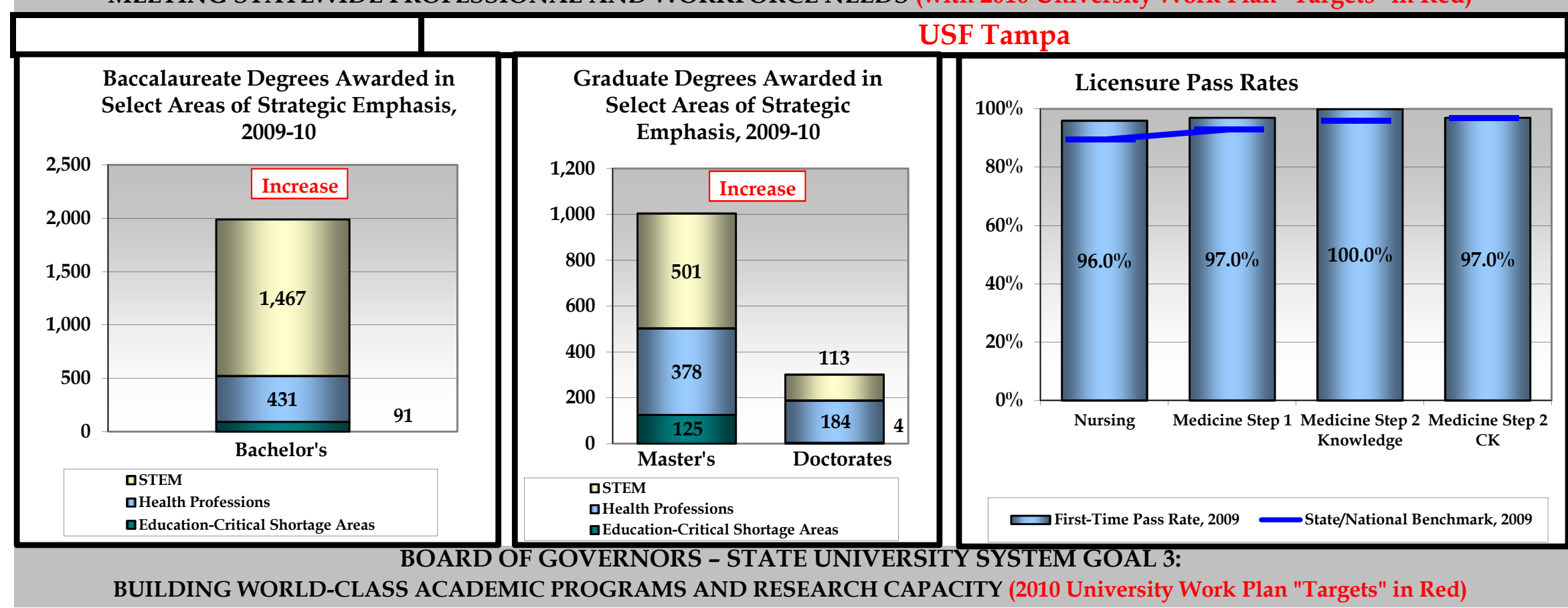

Academic Research and Development Expenditures
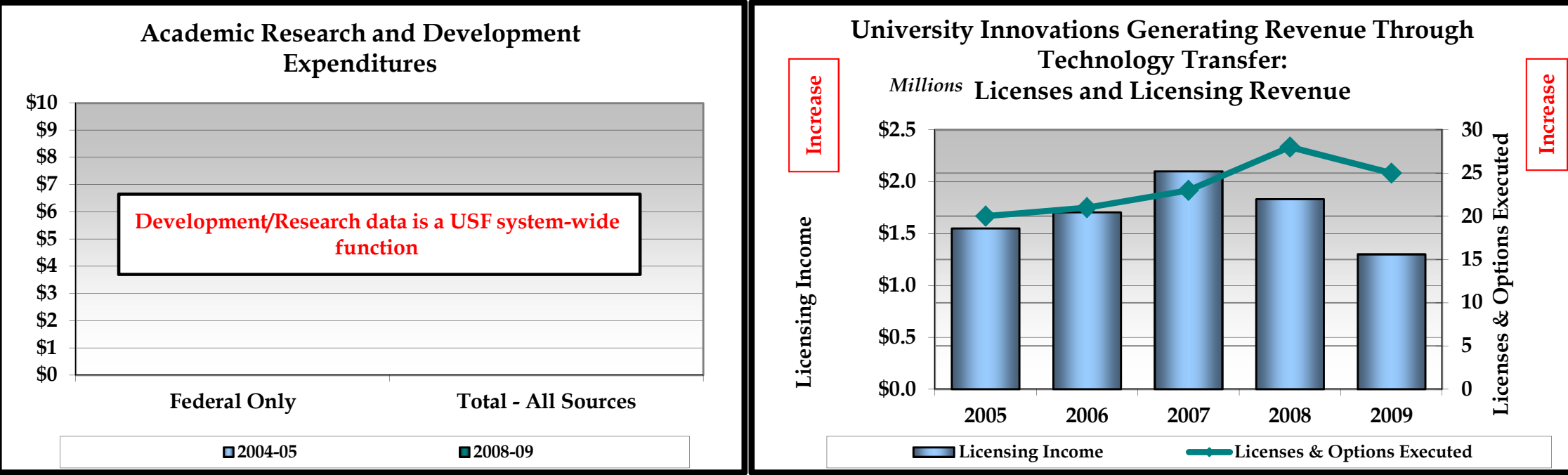

Projected Institutional Contributions in RED PRINT

(2012 - 2013 for Degrees in Areas of Strategic Emphasis; 2011 -2012 for R\&D, Licenses, and Licensing Revenue). 


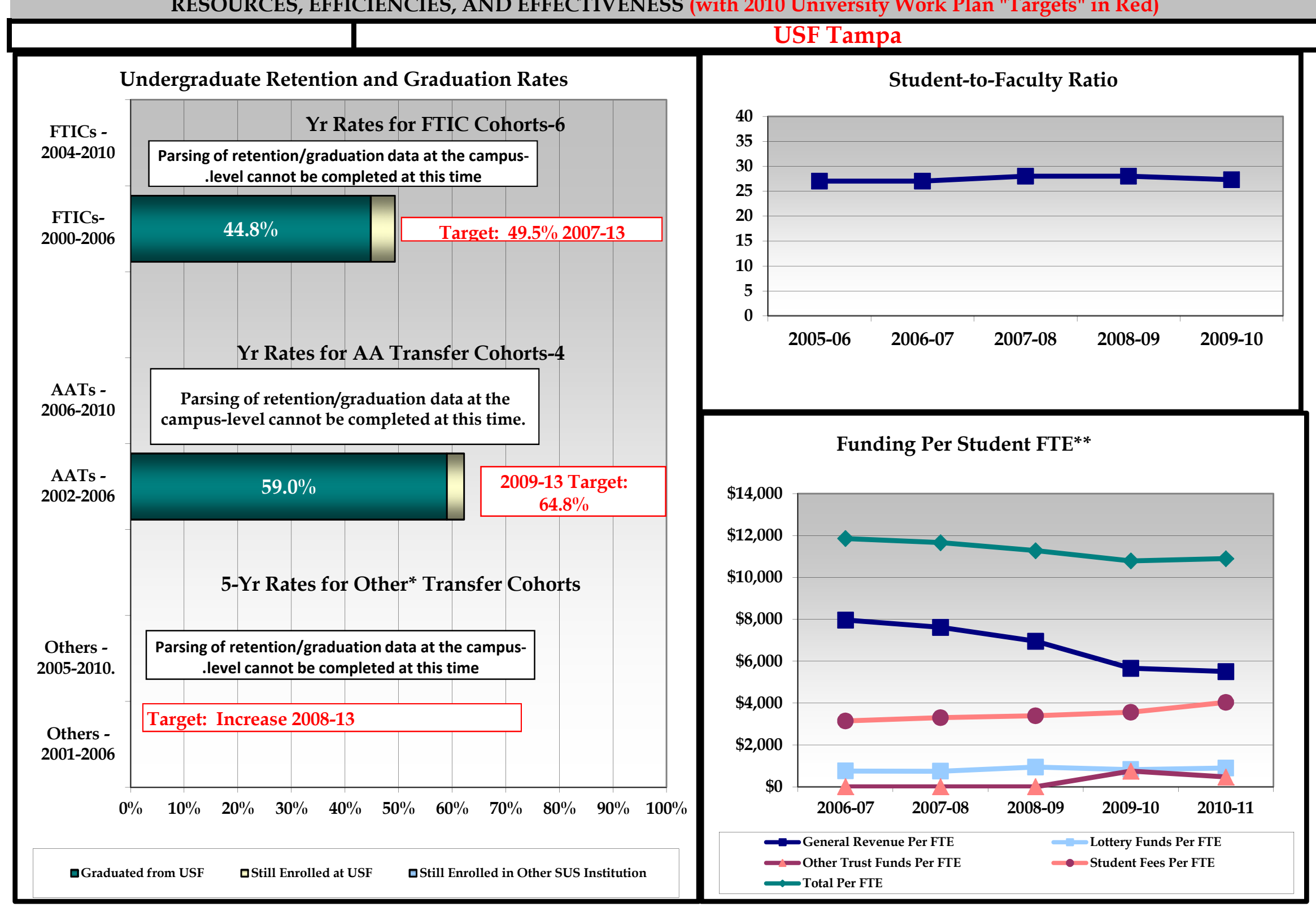

* The composition of "Other Transfer" cohorts may vary greatly by institution

** FTE for this metric uses the standard IPEDS definition of FTE, equal to 30 and by year.

credit hours for undergraduates and 24 for graduates.

Graduation Rate from SAME Institution - Projected Institutional Contributions in RED PRINT. 


\section{University of South Florida, Tampa}

\section{Key University Achievements}

\section{Student awards/achievements}

1. Student Success: Total of 9,229 Degrees awarded; Bachelors 6,572; Masters 2,241; EdS. 17; Research Doctoral 243; Professional Doctoral 156.

2. Awards: Three Fulbright Scholars; Two Gillman Scholarships; One Javits recipient; One BIG EAST Scholar; Short-listed World Architecture Design.

3. Awards: Two doctoral students NSF International Research \& Education in Engineering China program; one student placed top five winners in Chinese Bridge language competition.

\section{Faculty awards/achievements}

1. National Awards: Twelve faculty members received nationally recognized awards and five faculty received NSF CAREER awards, one a five-year award.

2. International Award: Jay Hopler recipient of a Rome Fellowship in Literature from the American Academy of Arts and Letters.

3. Fulbright Awards: Three research and administration.

\section{- Program awards/achievements}

1. Innovation: More than 100 inventors from across USF become members of National Academy of Inventors ${ }^{\mathrm{TM}}$.

2. New Programs: School of Global Sustainability (nation's first); College of Pharmacy; four doctoral programs.

3. New: Charter member of the Association for the Advancement of Sustainability in Higher Education.

\section{Research awards/achievements}

1. Partnerships: With Draper Laboratory, SRI Int., Mote Marine RI; hosts Florida Institute of Oceanography; houses Florida Center of Excellence for Biomolecular Identification and Targeted Therapeutics, partner Florida Energy Systems Consortium.

2. Grants $\mathcal{E}$ Patents: Total contracts and grants (FY10) $\$ 394.1 \mathrm{M}$ for research focusing in part on sustainability, neurosciences, diabetes, autoimmune diseases and veterans' re-integration. USF was awarded \$117 M over five years by NIH for the Rare Disease Clinical Research Network; developed 66 new patents and licenses. Drug created and patented - major partnership with global pharmaceutical company potentially earning USF lucrative patent royalties.

3. Rankings: USF ranked $110^{\text {th }}$ in the 2010 World University Rankings; $57^{\text {th }}$ of all universities and $33^{\text {rd }}$ of public institutions for federal research awards (FY09).

\section{Institutional awards/achievements}

1. Community Response: Immediate response to oil catastrophe Deepwater Horizon - \$10M for research.

2. Donations: The USF Foundation raised over $\$ 51 \mathrm{M}$ from more than 44,000 donors (Total more than $\$ 363 \mathrm{M}$ ).

3. Symposium on Afghanistan and Pakistan: featured world's leading authorities on Afghanistan and Pakistan, including Gen. David Petraeus. 


\section{INTRODUCTION}

University of South Florida, Tampa

\section{- Mission}

As Florida's leading public metropolitan research university, USF is dedicated to excellence in student access and success, research and scientific discovery, and innovation and collaborations.

\section{USF 2007-2012 Strategic Plan:}

http:// www.ods.usf.edu/Plans/Strategic/vision-mission.htm

\section{- Vision}

The University of South Florida envisions itself as a preeminent research university with state, national and global impact, and positioned for membership in the Association of American Universities (AAU).

USF 2007-2012 Strategic Plan:

http://www.ods.usf.edu/Plans/Strategic/vision-mission.htm

\section{- Other Contextual Introductory Comments}

USF consists of the main research campus in Tampa, which includes USF Health, USF Research Park, and USF College of Marine Science in St. Petersburg.

\section{BOARD OF GOVERNORS - STATE UNIVERSITY SYSTEM GOAL 1: ACCESS TO AND PRODUCTION OF DEGREES}

USF is committed to access and the success of its students. Production of degrees is a culmination of student experiences, achievements, and success at the institution, and therefore becomes a measure of student success. As such, student success (i.e., enhanced preparedness, retention, persistence, graduation and placement rates) has been the primary goal of undergraduate and graduate education initiatives.

In 2009-2010, USF awarded 9,229 degrees, of which more than 6,500 were bachelor's degrees, more than 2,200 were master's degrees, and nearly 300 were doctoral degrees.

At the undergraduate level, the university continues to make significant investments in programs and services to help students meet their fullest potential. The number of academic advisors has been increased again this year, tutoring services expanded, undergraduate research encouraged, new student orientation improved, residence halls remodeled, and policies updated. USF is taking a comprehensive approach to enhancing the undergraduate experience in an effort to improve graduation rates and the overall collegiate experience. Student success remains a primary objective of the institution.

In support of the university's strategic plan, graduate enrollment and diversity continue to rise - an indication of USF's commitment to strengthen its position as Florida's number two research university. Graduate studies and research are the hallmarks of the USF campus as a premier 
destination for world-class graduate students, postdoctoral fellows and faculty. Graduate and professional education at USF has been on a strong forward trajectory with exemplary educational and research opportunities for graduate students developed to promote our next state, national, and global leaders.

Both Graduate level I hours (master's courses) and Graduate level II (doctoral graduate hours) have increased 3\%. Diversity numbers are also strong, rising to $34.2 \%$ of all graduate students. The USF Graduate School is outperforming institutional goals for total number of doctorates awarded, particularly in STEM areas, and in international student enrollment. Continuing this trend prepares the nation's next generation of leaders, thinkers and scientists by replenishing the ranks of the professoriate for American higher education.

Approximately $36.5 \%$ of the undergraduate student body is comprised of students who identify themselves as races/ethnicities that are non-White. USF's student diversity is a hallmark of the institution and has been recognized by leading publications over the past several years.

Even with increased admission standards for transfer students, the USF System remains one of the nation's top destinations for transfer students. Historically, the USF System enrolls the most students transferring from the state's public community colleges, demonstrating its commitment to supporting Florida's ' $2+2$ ' system and the unique needs of transfer students.

Located in the heart of Tampa, USF is located less than 15 minutes from downtown, where the institution also maintains a center for professional and workforce education. USF
Health's presence permeates the Bay area through partnerships with hospitals and other health care organizations throughout Hillsborough County. The institution's broad geographic reach further supports its commitment to providing access to higher education.

\section{BOARD OF GOVERNORS - STATE UNIVERSITY SYSTEM GOAL 2: MEETING STATEWIDE PROFESSIONAL AND WORKFORCE NEEDS}

As a leading research university, USF offers a broad array of undergraduate and graduate degree programs preparing students to become leaders in business, industry, service, and research. Many degree programs align with state goals to meet professional and workforce needs, including education, health professions, the sciences, and emerging technologies.

The USF System significantly impacts the Florida economy through its basic and applied research (funded through external grants and contracts), business, commercial and hightechnological innovations, new high skilled and high wage job creation, and community engaged scholarship. The development of public-private partnerships facilitates teaching and research that benefit communities throughout the state and beyond. These partnerships include close ties with Draper Laboratory, SRI International, and the Mote Marine Research Institute. USF is host to the Florida Institute of Oceanography, houses the Florida Center of Excellence for Biomolecular Identification and Targeted Therapeutics (FCoEBITT/CDDI), and is an active partner in the Florida Energy Systems Consortium (FESC). 
USF's commitment to applied research is evident by a $175 \%$ increase in the total number of patents issued since 2004. Indeed, the USF System generated 66 new patents and licensing agreements during the year. A significant development was the creation and patenting of a drug in partnership with global pharmaceutical company AstraZeneca PLC and Targacept, Inc., potentially earning the university lucrative patent royalties.

USF promotes synergies among its members, serving as a major economic engine for the region and the state, by challenging its institutions to: increase the production of talented graduates in targeted, high demand fields; increase basic and applied research supported by the private sector and external funding; incubate a significant number of new companies, patents and licensing revenues; and enhance the quality of life through medical breakthroughs.

USF has a national and international impact that promotes the state's economic development and helps place it on the global stage. USF continues to expand its global activities,

international faculty exchanges, recruitment of full fee-paying international students, student education abroad programs, research collaborations, and service learning, thus boosting Florida's international competitiveness and place in the global economy. USF advances close partnerships with institutions of higher education from around the world providing additional opportunities in teaching and research for students and faculty, as well as preparing globally engaged graduates who compete successfully in the global marketplace of ideas.

Following the guidelines and selection of areas of strategic emphasis identified by the Board of Governors in consultation with business and industry groups, between 2004 and 2008, USF has experienced a positive growth trend in all identified areas (i.e., Education, Health Professions, STEM areas, Security \& Emergency Services, and Globalization,). From 2005 to 2009 , USF had a 35\% increase in total degrees awarded combined for all areas of strategic emphasis.

\begin{tabular}{|l|r|r|r|r|r|c|}
\hline USF & $\mathbf{2 0 0 5}$ & $\mathbf{2 0 0 6}$ & $\mathbf{2 0 0 7}$ & $\mathbf{2 0 0 8}$ & $\mathbf{2 0 0 9}$ & $\begin{array}{c}\mathbf{2 0 0 5} \\
\mathbf{- 0 9}\end{array}$ \\
\hline Education & 78 & 74 & 83 & 86 & 91 & $\mathbf{1 7 \%}$ \\
\hline Health Prof. & 338 & 435 & 401 & 414 & 431 & $\mathbf{2 8 \%}$ \\
\hline STEM & 1,049 & 1,199 & 1,231 & 1,324 & 1,467 & $\mathbf{4 0 \%}$ \\
\hline Security/Emergency & 243 & 295 & 318 & 325 & 346 & $\mathbf{4 2 \%}$ \\
\hline Globalization & 342 & 390 & 404 & 432 & 430 & $\mathbf{2 6 \%}$ \\
\hline Total & 2,050 & 2,393 & 2,437 & 2,581 & 2,765 & $\mathbf{3 5 \%}$ \\
\hline
\end{tabular}

\section{BOARD OF GOVERNORS - STATE UNIVERSITY SYSTEM GOAL 3: BUILDING WORLD-CLASS ACADEMIC PROGRAMS AND RESEARCH CAPACITY}

Research is a hallmark of every college, department and program at USF. It is an expectation and a privilege of every faculty member, whether it is sponsored by an external funding or carried out with support of university resources. As a result, there are many projects investigating basic research problems and tackling applied societal challenges that together all enhance our understanding of the world in the creation of new knowledge.

Approved by the USF System BOT-December $16^{\text {th }}, 2010$ 
Research is a centerpiece of the university's strategic plan, is fundamental to the recruitment and retention of top faculty and gives a university distinction. Consistent with the USF Strategic Plan, the university has four internationally recognized research themes which span the entire campus: sustainability, integrated neurosciences, diabetes, and drug design, development and delivery.

Under the basic classification of the Carnegie Foundation, USF is ranked in the highest category - a Research University with very high research activity $(\mathrm{RU} / \mathrm{VH})$ that grants doctoral degrees. As such, USF is competitive with similarly classified institutions. This classification reflects the distinguished quality of academic programs and research capacity, and the contribution they make to the creation of knowledge and technological innovation in building Florida's new economy. Adding to this distinguished quality of the academic programs and research capacity is the importance and impact of applied research.

USF ranked 110th in the 2010 World University Rankings of the top performing universities as measured by the research performance index (RPI), which is based on publications and citations of faculty research endeavors.

USF's research enterprise is also remarkable on the national level. In fiscal year 2008, USF ranked $64^{\text {th }}$ of total research and development expenditures (external funding) for all universities and colleges and $43^{\text {rd }}$ of all public institutions. In fiscal year 2009, USF ranked 33rd in federal research expenditures for public universities and $57^{\text {th }}$ for all universities. In FY2010, USF's funded research generated \$394.1 million in external awards from federal, state, industry, foundation and other sponsors who are our partners in discovery and innovation that benefits Florida citizens, develops and commercializes products, knowhow and processes, and creates start-up companies and jobs.

Research firmly connects the university with the local Tampa Bay community through service, outreach and engagement activities, the corporate community through patenting and licensing of technology and targeted research, with other academics through collaborative and cooperative programs and globally through our relationships with research colleagues. Research also connects the system through multidisciplinary approaches to a common problem. Research provides opportunity to students and prepares them for success in their chosen fields or for graduate and professional education.

USF was awarded $\$ 117$ million over the next five years by the National Institutes of Health in support of the second phase of its Rare Disease Clinical Research Network (RDCRN), which includes a Data Management Coordinating Center led by USF Professor and Chief of Epidemiology and Biostatistics Jeffrey Krischer. The research conducted with this second round of funding will explore the natural history, epidemiology, diagnosis and treatment of more than 95 rare diseases.

USF's commitment to applied research is evident by a $175 \%$ increase in the total number of patents issued since 2004.

Of equal importance, research and scholarship in the humanities and arts improve the quality of life for our citizens and elevate the reputation of USF through performances, works of art, published books and other writings, and public

Approved by the USF System BOT-December $16^{\text {th }}, 2010$ 
commentary. In support of the next generation of scholars, USF has established the Provost's Postdoctoral Scholars Initiative in Humanities and Social Sciences. This initiative supports five postdoctoral scholars in these areas and established an Office of Postdoctoral Affairs in the Graduate School for strategic planning and data collection related to all USF postdoctoral scholars. Overall, there has been a $149 \%$ increase in the number of postdoctoral scholars since 2004, with 261 postdoctorates reported for Fall 2009.

In 2009-10, three members of the USF faculty were identified as national academy members; 12 received nationally prestigious faculty awards as defined by the Top American Research Universities (TARU); and five received NSF CAREER awards. In addition, one faculty member was awarded the Rome Fellowship in Literature from the American Academy of Arts and Letters.

A reflection of the USF student success initiative, students were awarded three Fulbright Scholarships; two Gillman Scholarships; and one Javitz award. In addition one student was named a BIG EAST scholar, Architecture students were short listed for World Architecture Design Award; two doctoral students were selected NSF International Research \& Education in Engineering China program; and one student placed among top five winners at world Chinese Bridge language competition.

An overview of USF's 2009-10 Student \& Faculty Awards: http://usfweb3.usf.edu/infocenter/?report_category=SUR

\section{BOARD OF GOVERNORS - STATE UNIVERSITY SYSTEM GOAL 4: MEETING COMMUNITY NEEDS AND FULFILLING UNIQUE INSTITUTIONAL RESPONSIBILITIES}

USF is one of the nation's top research universities with a vibrant campus community and strong research focus. Between 2000 and 2007, no other American university grew its federal research enterprise at a faster rate than USF, (213\%) according to the Chronicle of Higher Education's 2009-10 Almanac.

This distinction is a clear example of USF's aspirations to become eligible for membership in the Association of American Universities (AAU), an organization of 63 leading public and private research universities in the U.S. and Canada (35 public, 26 private, 2 Canadian). A focus on meeting the stringent criteria for AAU invitation-only membership represents the highest level in which a university can benchmark its achievements.

USF's 2007-2012 Strategic Plan is a bold, ambitious plan to elevate the performance and rankings of USF and provides the USF community with a clear vision, goals, strategies and measures to promote alignment and success. It is clearly directed at ensuring student success, contributing innovation and new knowledge and advancing economic development in Florida, the nation, and globally.

A unique example of the integration of the USF Strategic Plan into the university's operations is the way USF incorporates the budget planning process into the implementation of the strategic planning process. USF aligns its budget with

Approved by the USF System BOT-December $16^{\text {th }}, 2010$ 
institutional strategic priorities through effectively communicating and engaging all stakeholders in a transparent, focused, and disciplined manner with a mind to preserving excellence; containing costs; leveraging efficiencies; generating new revenue; and maximizing performance.

USF's focus on integrated, interdisciplinary inquiry, one of the four pillars of the university's strategic plan, is evident both in instructional and research programs. From new doctoral programs to undergraduate research, graduate school partnerships, and community outreach initiatives, USF is positioned as an emerging global leader in a new way of approaching learning and discovery.

USF Health is an enterprise dedicated to making life better by improving health in the wider environment, in communities, and for individuals. USF Health has, as its core, the three colleges of Public Health, Nursing and Medicine, including a School of Physical Therapy as well as the healthcare delivered by its clinicians. Originally founded as the USF Medical Center in 1965, its name has been changed to USF Health to reflect its collaborative focus on the full continuum of health.

The establishment of the linked doctoral programs in history, government, and sociology is different from traditional, discipline-based programs. They focus on building sustainable healthy communities in a global context. These new programs join existing dual and interdisciplinary degree programs both at the undergraduate and graduate level.

In recognition of USF's service in the community, it was placed on the Corporation for National and Community Service's President's Higher Education Community Service
Honor Roll for exemplary service efforts and service to America's communities.

The USF Foundation raised over $\$ 51$ million from more than 44,000 donors, bringing the total amount raised on the USF: Unstoppable Campaign to more than \$363 million.

In furthering university interests, more than 100 inventors from across USF become members of National Academy of Inventors ${ }^{\mathrm{TM}}$.

Significantly, USF was uniquely placed to respond efficiently and effectively to the millions of gallons of oil that spewed into the Gulf beginning last April. From the outset, scientists and researchers from the University of South Florida's College of Marine Science mobilized to examine the spill, its potential flow patterns in the Gulf and its impact on the environment.

Research vessels outfitted with advanced equipment made frequent trips to gather valuable data. Scientists briefed members of Congress and USF experts were sought out by the media. The College of Marine Science remains an agile and dynamic resource for all information on the Gulf of Mexico and the spill.

\section{PROGRESS ON PRIMARY INSTITUTIONAL GOALS AND METRICS AS OUTLINED IN THE UNIVERSITY WORK PLAN}

USF serves as the core institution to the USF System but works collaboratively with the other three institutions to provide distinction in teaching, research and service. USF is a leading 
metropolitan research university, with a mission dedicated to excellence in:

- Student access and success in an engaged, and interdisciplinary, learner-centered environment,

- Research and scientific discovery, including the generation, dissemination, and translation of new knowledge across disciplines; to strengthen the economy; to promote civic culture and the arts; and to design and build sustainable, healthy communities, and

- Embracing innovation, and supporting scholarly and artistic engagement to build a community of learners together with significant and sustainable university-community partnerships and collaborations.

USF's comprehensive strategic plan guides the institution's advancement (http:/ / www.ods.usf.edu/Plans/Strategic) through five goals:

Goal 1: Student access and success;

Goal 2: Expanding world-class interdisciplinary research, creative, and scholarly endeavors;

Goal 3: Promoting globally competitive undergraduate, graduate and professional programs that support interdisciplinary inquiry, intellectual development, knowledge and skill acquisition, and student success through a diverse, fully- engaged, learner-centered campus environment;

Goal 4: Expanding local and global engagement initiatives to strengthen and sustain healthy communities and to improve the quality of life; and
Goal 5: Enhancing all sources of revenue, and maximizing effectiveness in business practices and financial management to establish a strong and sustainable economic base in support of USF's growth.

\section{Progress}

Progress has been made in all five goals over the years.

USF continues to make remarkable progress on its primary institutional goals. This can be seen from a quantitative perspective as shown in the array of data displayed on its dashboard and in the detailed matrix of variables through which the institution gauges its progress, as well as through qualitative advances, some of which are described below.

- USF Dashboard:

http://www.ods.usf.edu/Plans/PPA/dashboard.htm

- USF Matrix:

http://www.ods.usf.edu/Plans/PPA/matrix.htm

- Performance Update: Advancing USF's Strategic Plan, http:// www.ods.usf.edu/Support/2010-10-07BOT/AAU-performance-update.htm

Progress can also be seen through the example initiatives highlighted below:

INTO USF: USF and INTO University Partnerships embarked on a joint venture to increase international student recruitment at USF and ensure greater student success. The new

INTO >>USF international study center, based at USF, offers a unique range of programs that helps USF System capitalize on the growing number of international students seeking to study in the USA. The innovative year-long preparation courses

Approved by the USF System BOT-December $16^{\text {th }}, 2010$ 
provide international students with the specific academic, English and cultural skills needed for successful study in American universities. This initiative will continue to foster international accord and facilitate economic opportunities overseas for Floridians.

School of Global Sustainability: USF launched one of the nation's first Schools of Global Sustainability in February 2010, an innovative effort aimed at preparing students for a new generation of "green collar" careers and finding solutions for a world challenged with the protection of its fragile environment and limited resources. Employment opportunities in this area are growing and Florida needs to be on the cutting edge

The first degree program to be offered by the school is a Master of Arts (MA) in Global Sustainability to prepare students to address complex regional, national, and global challenges related to sustainability and the ability to innovate in diverse cultural, geographic, and demographic contexts. The multi-disciplinary program incorporates the natural and social sciences, engineering, health, economics, governance and policy, and issues of diversity.

Global Academic Partners Program: The Global Academic Partners Program provides for mutually beneficial collaboration in research, teaching, and creative activities between USF and its Global Academic Partner Universities. Current partners are: Nankai University and Ocean University in China, University of Exeter in the United Kingdom, University of Ghana, and University of the Cape Coast, in Ghana. Fostering better international relations will facilitate connections between countries and hence facilitate economic development.

\section{ADDITIONAL INFORMATION ON QUALITY, RESOURCES, EFFICIENCIES, AND EFFECTIVENESS}

The USF System provides central services through several offices: 1) Audit \& Compliance, 2) Diversity \& Equal Opportunity, 3) General Counsel, 4) Government Relations, and 5) Special Events and Ceremonies. An annual cost allocation for services from these offices is distributed to each campus in the USF System to ensure consistency in implementation of USF System regulations and policies and to avoid duplication of the system-wide central services.

Other USF offices also provide services to all campuses within the USF System, for example: 1) Enterprise business systems, e.g., FAST, GEMS, FAIR for student, employee and financial data; 2) purchasing and accounting; 3) Research and Innovation for research compliance and grant/contract proposals, awards and management; 3) USF Libraries; 4) Financial Aid; 5) International Affairs; 6) Decision Support; 7) University Advancement; 8) Information Technology; 9) Communications and Marketing. Again, an annual cost allocation for services from these offices is distributed to each campus in the USF System.

PaperFree Florida, an initiative started by USF Health to jumpstart America's electronic health revolution to convert physicians from paper prescriptions to electronic prescribing, received a $\$ 6$ million grant in federal stimulus funds to help doctors in a 20-county area move towards electronic health

Approved by the USF System BOT-December $16^{\text {th }}, 2010$ 
records. This award supports one of the first regional initiatives in the nation to invest recovery dollars in a whole new professional work force combining health and information technology.

\section{ADDITIONAL RESOURCES}

- Carnegie Classification

Basic: RU/VH: Research Universities (very high research activity)

- Community Engagement: Outreach \& Partnerships

- Undergraduate Instructional Program:

CompDoc/MedVet: Comprehensive doctoral with medical/veterinary

- Graduate Instructional Program: Bal/HGC: Balanced arts \& sciences/professions, high graduate coexistence

- Enrollment Profile: HU: High undergraduate

- Undergraduate Profile: MFT4/S/HTI: Medium full-time four-year, selective, higher transfer-in

- Size and Setting: L4/NR: Large four-year, primarily nonresidential

http://www.carnegiefoundation.org/classifications/

- Voluntary System of Accountability College Portrait of Undergraduate Education

http://www.collegeportraits.org/FL/USF

Common Data Set

http://usfweb3.usf.edu/infocenter/?silverheader=2\&report_c ategory $=$ SUR\&report_type $=$ CDSUR
College Navigator

http://nces.ed.gov/collegenavigator/?q=South+Florida\&s=F L\&id=137351

- Comparative Data

Performance Update: Advancing USF's Strategic Plan: http:// www.ods.usf.edu/Support/2010-10-07-BOT/ AAUperformance-update.htm

USF Office of Research \& Innovation http://www.research.usf.edu/

- University Strategic Plan http://system.usf.edu/pdfs/USF_System_Strategic_Plan.pdf

- University Data Sources

USF Planning, Performance and Accountability: http://www.ods.usf.edu/Plans/PPA/matrix.htm

USF e-Profiles:

http://usfweb3.usf.edu/eprofiles/

USF InfoCenter:

http://usfweb3.usf.edu/infocenter/

USF Performance Dashboard:

http://www.ods.usf.edu/Plans/PPA/dashboard.htm

USF Peers:

http://www.ie.usf.edu/Peer/ 


\section{Section 1 - Financial Resources (including Health-Science Center \& IFAS, if applicable)}

Table 1A. Education and General Revenues

Table 1B. Education and General Expenditures

Table 1C. Funding per Student

Table 1D. Other Budget Entities

Table 1E. Total Revenues and Expenditures

Table 1F. Voluntary Support of Higher Education

Table 1G. Federal Stimulus Dollars (ARRA)

\section{Section 2 - Personnel}

Table 2A. Personnel Headcount

\section{Section 3 - Enrollment \& Space}

Table 3A. University Full-time Enrollment (FTE)

Table 3B. Enrollment by Location

Table 3C. Space Utilization

\section{Section 4 - Undergraduate Education}

Table 4A. Baccalaureate Degree Program Changes in AY 2009-2010

Table 4B. $\quad$ First-Year Persistence Rates

Table 4C. Federal Definition - Undergraduate Progression and Graduation Rates

for Full-time First-time-in-College (FTIC) Students

Table 4D. SUS - Undergraduate Progression and Graduation Rates

for First-time-in-College (FTIC) Students

Table 4E. SUS - Undergraduate Progression and Graduation Rates for AA Transfer Students

Table 4F. $\quad$ SUS - Undergraduate Progression and Graduation Rates

$$
\text { for Other Transfer Students }
$$

Table 4G. Baccalaureate Degrees Awarded

Table 4H. Baccalaureate Degrees Awarded in Areas of Strategic Emphasis

Table 4I. Baccalaureate Degrees Awarded to Underrepresented Groups

Table 4J. Baccalaureate Completion Without Excess Credit Hours

Table 4K. Undergraduate Course Offerings

Table 4L. Faculty Teaching Undergraduates

Table 4M. Undergraduate Instructional Faculty Compensation

Table 4 N. Student/Faculty Ratio

Table 4O. Licensure Pass Rates

Table 4P. Tuition Differential Fee

\section{Section 5 - Graduate Education}

Table 5A. Graduate Degree Programs Changes in AY 2009-2010

Table 5B. Graduate Degrees Awarded

Table 5C. Graduate Degrees Awarded in Areas of Strategic Emphasis

Table 5D. Licensure Pass Rates

\section{Section 6 - Research and Economic Development}

Table 6A. Research and Development

Table 6B. Centers of Excellence

Table 6C. State University Research Commercialization Assistance Grants

Table 6D. 21st Century World Class Scholars Program

\section{Appendix I - Definitions}




\begin{tabular}{|c|c|c|c|c|c|}
\hline \multicolumn{6}{|c|}{$\begin{array}{l}\text { STATE UNIVERSITY SYSTEM - } 2010 \text { ANNUAL REPORT } \\
\text { Section } 1 \text { - Financial Resources }\end{array}$} \\
\hline \multicolumn{6}{|c|}{\begin{tabular}{|c|} 
University of South Florida--Tampa \\
\end{tabular}} \\
\hline \multicolumn{6}{|c|}{ Table 1A. University Education and General Revenues* } \\
\hline & $\begin{array}{r}2006-07 \\
\text { Actual } \\
\end{array}$ & $\begin{array}{r}2007-08 \\
\text { Actual } \\
\end{array}$ & $\begin{array}{r}2008-09 \\
\text { Actual } \\
\end{array}$ & $\begin{array}{r}2009-10 \\
\text { Actual } \\
\end{array}$ & $\begin{array}{c}2010-11 \\
\text { Estimates }\end{array}$ \\
\hline $\begin{array}{l}\text { Recurring State Funds } \\
\text { (GR \& Lottery) }\end{array}$ & $\$ 235,905,307$ & $\$ 238,733,135$ & $\$ 218,374,574$ & $\$ 194,273,508$ & $\$ 196,892,639$ \\
\hline $\begin{array}{c}\text { Non-Recurring State Funds } \\
\text { (GR \& Lottery) }\end{array}$ & $\$ 28,560,000$ & $\$ 7,874,087$ & $\$ 13,358,066$ & $\$ 1,277,889$ & $\$ 1,398,322$ \\
\hline $\begin{array}{c}\text { Tuition } \\
\text { (Resident/Non-Resident) } \\
\end{array}$ & $\$ 89,914,042$ & $\$ 93,427,618$ & $\$ 93,118,003$ & $\$ 97,239,652$ & $\$ 95,950,000$ \\
\hline Tuition Differential Fee & $\$ 0$ & $\$ 0$ & $\$ 2,626,024$ & $\$ 6,711,769$ & $\$ 12,364,253$ \\
\hline $\begin{array}{c}\text { Other Revenues } \\
\text { (Includes Misc. Fees E Fines) }\end{array}$ & $\$ 2,784,454$ & $\$ 3,848,306$ & $\$ 3,838,564$ & $\$ 3,409,948$ & $\$ 3,080,834$ \\
\hline $\begin{array}{c}\text { Phosphate Research } \\
\text { Trust Fund } \\
\end{array}$ & $\$ 7,141,734$ & $\$ 7,268,856$ & $\$ 7,287,963$ & $\$ 7,304,684$ & $\$ 0$ \\
\hline Federal Stimulus Funds & $\$ 0$ & $\$ 0$ & $\$ 0$ & $\$ 15,145,041$ & $\$ 14,491,582$ \\
\hline TOTAL & $\$ 364,305,537$ & $\$ 351,152,002$ & $\$ 338,603,194$ & $\$ 325,362,491$ & $\$ 324,177,630$ \\
\hline
\end{tabular}

*Note: 2010-11 estimates for the USF System report are accepted at the request of the BOG. It should be noted however, that a discrepancy in the amount of transfers between the main campus and HSC is reflected in this table and in the HSC corresponding table. In turn, the individual campus reports will not roll up to these reflected totals and will corrections will be reflected in the 2011 Annual Report.

\begin{tabular}{|c|c|c|c|c|c|}
\hline & $\begin{array}{l}\text { 2006-07 } \\
\text { Actual }\end{array}$ & $\begin{array}{c}2007-08 \\
\text { Actual }\end{array}$ & $\begin{array}{r}2008-09 \\
\text { Actual }\end{array}$ & $\begin{array}{r}2009-10 \\
\text { Actual }\end{array}$ & $\begin{array}{c}\text { 2010-11 } \\
\text { Estimates }\end{array}$ \\
\hline Instruction/Research & $\$ 217,514,787$ & $\$ 211,445,741$ & $\$ 195,633,873$ & $210,298,415$ & $\$ 259,052,058$ \\
\hline Institutes and Research Centers & $\$ 1,234,810$ & $\$ 1,193,341$ & $\$ 1,024,089$ & $\$ 968,072$ & $\$ 773,687$ \\
\hline PO\&M & $\$ 32,025,878$ & $\$ 33,466,687$ & $\$ 31,870,980$ & $\$ 29,960,884$ & $\$ 32,385,084$ \\
\hline $\begin{array}{c}\text { Administration } \\
\text { and Support Services }\end{array}$ & $\$ 15,399,086$ & $\$ 14,242,463$ & $\$ 20,795,141$ & $\$ 15,737,708$ & $\$ 22,310,683$ \\
\hline Radio/TV & $\$ 953,802$ & $\$ 861,952$ & $\$ 815,056$ & $\$ 892,242$ & $\$ 937,916$ \\
\hline Library/Audio Visual & $\$ 11,886,131$ & $\$ 12,096,969$ & $\$ 11,945,995$ & $\$ 11,694,131$ & $\$ 11,595,620$ \\
\hline Museums and Galleries & $\$ 764,217$ & $\$ 740,451$ & $\$ 729,951$ & $\$ 640,699$ & $\$ 586,476$ \\
\hline Agricultural Extension & $\$ 0$ & $\$ 0$ & $\$ 0$ & $\$ 0$ & $\$ 0$ \\
\hline Allied Clinics & $\$ 0$ & $\$ 0$ & $\$ 0$ & $\$ 0$ & $\$ 0$ \\
\hline Student Services & $\$ 11,861,623$ & $\$ 18,631,075$ & $\$ 17,967,815$ & $\$ 17,871,933$ & $\$ 17,173,181$ \\
\hline Intercollegiate Athletics & $\$ 771,412$ & $\$ 513,486$ & $\$ 352,411$ & $\$ 356,213$ & $\$ 364,146$ \\
\hline TOTAL & $\$ 292,411,746$ & $\$ 293,192,165$ & $\$ 281,135,309$ & $\$ 288,420,297$ & $\$ 345,178,851$ \\
\hline
\end{tabular}


The table reports the actual and estimated amount of expenditures from revenues appropriated by the legislature for each fiscal year. The expenditures are classified by Program Component (i.e., Instruction/Research, PO\&M, Administration, etc...) for activities directly related to instruction, research and public service. The table does not include expenditures classified as non-operating expenditures (i.e., to service asset-related debts), and therefore excludes a small portion of the amount appropriated each year by the legislature. Also, the table does not include expenditures from funds carried forward from previous years. 


\begin{tabular}{|c|c|c|c|c|c|}
\hline \multicolumn{6}{|c|}{$\begin{array}{l}\text { STATE UNIVERSITY SYSTEM - } 2010 \text { ANNUAL REPORT } \\
\text { Section } 1 \text { - Financial Resources }\end{array}$} \\
\hline \multicolumn{6}{|c|}{ University of South Florida--Tampa } \\
\hline \multicolumn{6}{|c|}{ Table 1C. Funding per Full-Time Equivalent (FTE) Student ** } \\
\hline & 2006-07 & $2007-08$ & 2008-09 & 2009-10 & 2010-11 \\
\hline \multicolumn{6}{|l|}{ Appropriated Funding per FTE } \\
\hline General Revenue per FTE & $\$ 7,960$ & $\$ 7,614$ & $\$ 6,951$ & $\$ 5,660$ & $\$ 5,498$ \\
\hline Lottery Funds per FTE & $\$ 753$ & $\$ 742$ & $\$ 934$ & $\$ 821$ & $\$ 892$ \\
\hline $\begin{array}{l}\text { Tuition \& Fees per FTE } \\
\text { (based on Budget Authority) }\end{array}$ & $\$ 3,139$ & $\$ 3,297$ & $\$ 3,388$ & $\$ 3,558$ & $\$ 4,031$ \\
\hline Other Trust Funds per FTE & $\$ 0$ & $\$ 0$ & $\$ 0$ & $\$ 744$ & $\$ 467$ \\
\hline Total per FTE & $\$ 11,852$ & $\$ 11,653$ & $\$ 11,273$ & $\$ 10,783$ & $\$ 10,888$ \\
\hline Actual Funding per FTE & 2006-07 & $2007-08$ & 2008-09 & 2009-10 & est. $2010-11$ \\
\hline $\begin{array}{l}\text { Tuition \& Fees per FTE } \\
\text { (based on Actual Collections) }\end{array}$ & $\$ 3,139$ & $\$ 3,297$ & $\$ 3,388$ & $\$ 3,558$ & $\$ 3,590$ \\
\hline Actual Total per FTE & $\$ 11,852$ & $\$ 11,653$ & $\$ 11,273$ & $\$ 10,783$ & $\$ 10,447$ \\
\hline \multicolumn{6}{|c|}{$\begin{array}{l}\text { *Note: Change to reporting of these data on funding per student FTE may result in differences in years prior to 2009-10 as } \\
\text { history was not modified to reflect the new reporting methodology. }\end{array}$} \\
\hline \multirow{2}{*}{\multicolumn{6}{|c|}{$\begin{array}{l}\text { **Note: Figures are approved for the } 2010 \text { Annual Report but it should be noted however,discrepancies due to transfers not } \\
\text { reflected in this report may result; figures will be corrected in the following annual report. } \\
\text { Notes: (1) FTE is based on actual FTE, not funded FTE; (2) Does not include Health-Science Center funds or FTE; (3) } \\
\text { FTE for these metrics uses the standard IPEDS definition of FTE, equal to } 30 \text { credit hours for undergraduates and } 24 \\
\text { for graduates; and (4) Actual funding per student is based on actual tuition and E\&G fees (does not include local fees) } \\
\text { collected. }\end{array}$}} \\
\hline & & & & & \\
\hline \multicolumn{6}{|c|}{ Table 1D. University Other Budget Entities } \\
\hline & $\begin{array}{r}2006-07 \\
\text { Actual }\end{array}$ & $\begin{array}{r}2007-08 \\
\text { Actual }\end{array}$ & $\begin{array}{r}2008-09 \\
\text { Actual }\end{array}$ & $\begin{array}{r}2009-10 \\
\text { Actual }\end{array}$ & $\begin{array}{c}2010-11 \\
\text { Estimates }\end{array}$ \\
\hline \multicolumn{6}{|l|}{ Contracts \& Grants } \\
\hline Revenues & \multirow{2}{*}{\multicolumn{5}{|c|}{ Contracts \& Grants data is a USF system-wide function and consolidated system data is only available at this time. }} \\
\hline Expenditures & & & & & \\
\hline \multicolumn{6}{|l|}{ Auxiliary Enterprises } \\
\hline Revenues & \multirow{2}{*}{\multicolumn{5}{|c|}{ Contracts \& Grants data is a USF system-wide function and consolidated system data is only available at this time. }} \\
\hline Expenditures & & & & & \\
\hline \multicolumn{6}{|l|}{ Local Funds } \\
\hline Revenues & \multirow{2}{*}{\multicolumn{5}{|c|}{ Contracts \& Grants data is a USF system-wide function and consolidated system data is only available at this time. }} \\
\hline Expenditures & & & & & \\
\hline \multicolumn{6}{|c|}{ Table 1E. University's Total Revenues and Expenditures } \\
\hline & $\begin{array}{r}2006-07 \\
\text { Actual }\end{array}$ & $\begin{array}{r}2007-08 \\
\text { Actual }\end{array}$ & $\begin{array}{r}\text { 2008-09 } \\
\text { Actual }\end{array}$ & $\begin{array}{r}2009-10 \\
\text { Actual }\end{array}$ & $\begin{array}{c}2010-11 \\
\text { Estimates }\end{array}$ \\
\hline Revenues & $\$ 364,305,537$ & $\$ 351,152,002$ & $\$ 338,603,194$ & $\$ 325,362,491$ & $\$ 324,177,630$ \\
\hline Expenditures & $\$ 292,411,746$ & $\$ 293,192,165$ & $\$ 281,135,309$ & $\$ 288,420,297$ & $\$ 345,178,851$ \\
\hline
\end{tabular}


*Note: 2010-11 estimates for the USF System report are accepted at the request of the BOG. It should be noted however, that a discrepancy in the amount of transfers between the main campus and HSC is reflected in this table and in the HSC corresponding table. In turn, the individual campus reports will not roll up to these reflected totals and will corrections will be reflected in the 2011 Annual Report. 


\begin{tabular}{|c|c|c|c|c|c|}
\hline \multicolumn{6}{|c|}{$\begin{array}{l}\text { STATE UNIVERSITY SYSTEM - } 2010 \text { ANNUAL REPORT } \\
\text { Section } 1 \text { - Financial Resources }\end{array}$} \\
\hline \multicolumn{6}{|c|}{ University of South Florida--Tampa } \\
\hline \multicolumn{6}{|c|}{ Table 1F. Voluntary Support of Higher Education } \\
\hline & 2004-2005 & 2005-2006 & 2006-2007 & $2007-2008$ & 2008-2009 \\
\hline $\begin{array}{c}\text { Endowment Market Value } \\
\text { (Thousand \$) }\end{array}$ & \multirow{3}{*}{\multicolumn{5}{|c|}{$\begin{array}{l}\text { Development/Research data is a USF system-wide function. Consolidated system } \\
\text { data is only available at this time. }\end{array}$}} \\
\hline $\begin{array}{c}\text { Annual Gifts Received } \\
(\$)\end{array}$ & & & & & \\
\hline $\begin{array}{c}\text { Percentage of Graduates Who } \\
\text { Are Alumni Donors }\end{array}$ & & & & & \\
\hline
\end{tabular}

\begin{tabular}{|l|c|c|}
\hline Table 1G. University Federal Stimulus Dollars (ARRA) \\
\hline Proposed Operating Budget Detail & Actual 2009-10 & Proposed 2010-11 \\
\hline Jobs Saved/Created & & $\$ 14,491,582$ \\
\hline Scholarships & $\$ 15,145,041$ & $\$ 0$ \\
\hline Library Resources & $\$ 0$ & $\$ 0$ \\
\hline Building Repairs/Alterations & $\$ 0$ & $\$ 0$ \\
\hline Motor Vehicles & $\$ 0$ & $\$ 0$ \\
\hline Printing & $\$ 0$ & $\$ 0$ \\
\hline Furniture \& Equipment & $\$ 0$ & $\$ 0$ \\
\hline Information Technology Equipment & $\$ 0$ & $\$ 0$ \\
\hline Financial Aid to Medical Students & $\$ 0$ & $\$ 0$ \\
\hline Other: & $\$ 0$ & $\$ 0$ \\
\hline TOTAL & $\$ 15,145,041$ & $\$ 14,491,582$ \\
\hline
\end{tabular}




\begin{tabular}{|c|c|c|c|c|c|}
\hline \multicolumn{6}{|c|}{$\begin{array}{c}\text { STATE UNIVERSITY SYSTEM - } 2010 \text { ANNUAL REPORT } \\
\text { Section } 1 \text { - Financial Resources (Health-Science Center) }\end{array}$} \\
\hline \multicolumn{6}{|c|}{ University of South Florida--Tampa } \\
\hline \multicolumn{6}{|c|}{ Table 1A. Health-Science Center Education and General Revenues } \\
\hline & $\begin{array}{r}2006-07 \\
\text { Actual }\end{array}$ & $\begin{array}{c}2007-08 \\
\text { Actual }\end{array}$ & $\begin{array}{c}\text { 2008-09 } \\
\text { Actual }\end{array}$ & $\begin{array}{c}2009-10 \\
\text { Actual }\end{array}$ & $\begin{array}{c}2010-11 \\
\text { Estimates }\end{array}$ \\
\hline $\begin{array}{l}\text { Recurring State Funds } \\
\quad(\text { GR \& Lottery })\end{array}$ & $\$ 65,740,706$ & $\$ 65,814,423$ & $\$ 62,041,950$ & $\$ 60,968,084$ & $\$ 63,214,480$ \\
\hline $\begin{array}{l}\text { Non-Recurring State Funds } \\
\text { (GR \& Lottery) }\end{array}$ & $\$ 1,002,981$ & $\$ 929,801$ & $\$ 635,338$ & $\$ 221,238$ & $\$ 1,000,000$ \\
\hline $\begin{array}{c}\text { Tuition } \\
\text { (Resident/Non-Resident) } \\
\end{array}$ & $\$ 17,974,839$ & $\$ 22,648,230$ & $\$ 26,347,362$ & $\$ 29,988,216$ & $\$ 29,939,082$ \\
\hline Tuition Differential Fee & $\$ 0$ & $\$ 0$ & $\$ 111,799$ & $\$ 501,511$ & $\$ 995,431$ \\
\hline $\begin{array}{c}\text { Other Revenues } \\
\text { (Includes Misc. Fees \& Fines) }\end{array}$ & $\$ 4,678,832$ & $\$ 0$ & $\$ 0$ & $\$ 1,331$ & $\$ 0$ \\
\hline Federal Stimulus Funds & $\$ 0$ & $\$ 0$ & $\$ 0$ & $\$ 4,569,090$ & $\$ 4,351,772$ \\
\hline TOTAL & $\$ 89,397,358$ & $\$ 89,392,454$ & $\$ 89,136,449$ & $\$ 96,249,470$ & $\$ 99,500,765$ \\
\hline
\end{tabular}

*Note: 2010-11 estimates for the USF System report are accepted at the request of the BOG. It should be noted however, that a discrepancy in the amount of $\$ 1.6 \mathrm{M}$ consisting of transfers between the main campus and HSC is reflected in this table and in the HSC corresponding table. In turn, the individual campus reports will not roll up to these reflected totals and will corrections will be reflected in the 2011 Annual Report.

\begin{tabular}{|c|c|c|c|c|c|}
\hline & $\begin{array}{r}2006-07 \\
\text { Actual } \\
\end{array}$ & $\begin{array}{r}2007-08 \\
\text { Actual } \\
\end{array}$ & $\begin{array}{r}\text { 2008-09 } \\
\text { Actual } \\
\end{array}$ & $\begin{array}{r}2009-10 \\
\text { Actual } \\
\end{array}$ & $\begin{array}{c}2010-11 \\
\text { Estimates } \\
\end{array}$ \\
\hline Instruction/Research & $\$ 63,448,633$ & $\$ 64,625,114$ & $\$ 64,047,565$ & $\$ 68,082,736$ & $\$ 94,395,248$ \\
\hline $\begin{array}{c}\text { Institutes and Research } \\
\text { Centers }\end{array}$ & $\$ 202,840$ & $\$ 154,396$ & $\$ 1,153$ & $\$ 0$ & $\$ 0$ \\
\hline PO\&M & $\$ 90,778$ & $\$ 64,095$ & $\$ 262,695$ & $\$ 84,684$ & $\$ 1,992,534$ \\
\hline $\begin{array}{c}\text { Administration } \\
\text { and Support Services }\end{array}$ & $\$ 4,797,748$ & $\$ 5,200,070$ & $\$ 4,463,186$ & $\$ 5,033,763$ & $\$ 6,763,572$ \\
\hline Library/Audio Visual & $\$ 3,008,725$ & $\$ 2,903,725$ & $\$ 2,787,282$ & $\$ 2,473,154$ & $\$ 2,464,944$ \\
\hline $\begin{array}{l}\text { Teaching Hospital } \\
\text { \& Allied Clinics }\end{array}$ & $\$ 0$ & $\$ 0$ & $\$ 0$ & $\$ 0$ & $\$ 0$ \\
\hline TOTAL & $\$ 71,548,724$ & $\$ 72,947,400$ & $\$ 71,561,881$ & $\$ 75,674,337$ & $\$ 105,616,298$ \\
\hline \multicolumn{6}{|c|}{ Table 1D. Health-Science Center Other Budget Entities } \\
\hline & $\begin{array}{c}2006-07 \\
\text { Actual }\end{array}$ & $\begin{array}{c}2007-08 \\
\text { Actual }\end{array}$ & $\begin{array}{c}2008-09 \\
\text { Actual }\end{array}$ & $\begin{array}{c}2009-10 \\
\text { Actual }\end{array}$ & $\begin{array}{c}2010-11 \\
\text { Estimates }\end{array}$ \\
\hline \multicolumn{6}{|l|}{ Faculty Practice Plans } \\
\hline Revenues & \multirow{2}{*}{\multicolumn{5}{|c|}{$\begin{array}{l}\text { Data related to Faculty Practice Plans } \\
\text { will be included in the } 2011 \text { Annual Report. }\end{array}$}} \\
\hline Expenditures & & & & & \\
\hline \multicolumn{6}{|c|}{$\begin{array}{l}\text { Note: All Contracts \& Grants activities (for E\&G, Health Science Centers and IFAS) are managed and reported by each } \\
\text { institution's Division of Sponsored Research, thus are all reported in the University Other Budget Entities table. }\end{array}$} \\
\hline \multicolumn{6}{|c|}{ Table 1E. Health-Science Center Total Revenues and Expenditures } \\
\hline Revenues & $\$ 89,397,358$ & $\$ 89,392,454$ & $\$ 89,136,449$ & $\$ 96,249,470$ & $\$ 99,500,765$ \\
\hline Expenditures & $\$ 71,548,724$ & $\$ 72,947,400$ & $\$ 71,561,881$ & $\$ 75,674,337$ & $\$ 105,616,298$ \\
\hline
\end{tabular}


*Note: 2010-11 estimates for the USF System report are accepted at the request of the BOG. It should be noted however, that a discrepancy in the amount of $\$ 1.6 \mathrm{M}$ consisting of transfers between the main campus and HSC is reflected in this table and in the HSC corresponding table. In turn, the individual campus reports will not roll up to these reflected totals and will corrections will be reflected in the 2011 Annual Report. 


\begin{tabular}{|l|c|c|}
\hline \multicolumn{3}{|c|}{ STATE UNIVERSITY SYSTEM - 2010 ANNUAL REPORT } \\
Section 1 - Financial Resources (Health-Science Center) \\
\hline \multicolumn{3}{|c|}{ University of South Florida--Tampa } \\
\hline Table 1G. Health-Science Center Federal Stimulus Dollars (ARRA) \\
\hline \multicolumn{2}{|c|}{ Actual 2009-10 } & Proposed 2010-11 \\
\hline Proposed Operating Budget Detail & $\$ 4,569,090$ & $\$ 4,351,772$ \\
\hline Jobs Saved/Created & $\$ 0$ & $\$ 0$ \\
\hline Scholarships & $\$ 0$ & $\$ 0$ \\
\hline Library Resources & $\$ 0$ & $\$ 0$ \\
\hline Building Repairs/Alterations & $\$ 0$ & $\$ 0$ \\
\hline Motor Vehicles & $\$ 0$ & $\$ 0$ \\
\hline Printing & $\$ 0$ & $\$ 0$ \\
\hline Furniture \& Equipment & $\$ 0$ & $\$ 0$ \\
\hline Information Technology Equipment & $\$ 0$ & $\$ 0$ \\
\hline Financial Aid to Medical Students & $\$ 0$ & $\$ 4,351,772$ \\
\hline Other: & $\$ 4,569,090$ & \\
\hline TOTAL & & \\
\hline
\end{tabular}


STATE UNIVERSITY SYSTEM - 2010 ANNUAL REPORT

Section 2 - Personnel

\section{University of South Florida--Tampa}

\section{Table 2A. Personnel Headcount}

\begin{tabular}{|c|c|c|c|c|c|c|c|c|c|c|}
\hline & \multicolumn{2}{|c|}{ Fall 2005} & \multicolumn{2}{|c|}{ Fall 2006} & \multicolumn{2}{|c|}{ Fall 2007} & \multicolumn{2}{|c|}{ Fall 2008} & \multicolumn{2}{|c|}{ Fall 2009} \\
\hline & FT & PT & FT & PT & FT & PT & FT & PT & FT & PT \\
\hline $\begin{array}{c}\text { Faculty } \\
\text { Tenure/ Tenure-track }\end{array}$ & 1,049 & 85 & 1,076 & 75 & 1,034 & 77 & 969 & 78 & 980 & 78 \\
\hline $\begin{array}{c}\text { Faculty } \\
\text { Non-Tenure Track }\end{array}$ & 434 & 149 & 480 & 147 & 519 & 153 & 416 & 132 & 444 & 132 \\
\hline $\begin{array}{l}\text { Instructors Without } \\
\text { Faculty Status }\end{array}$ & 0 & 0 & 0 & 0 & 0 & 0 & 0 & 0 & 0 & 0 \\
\hline $\begin{array}{c}\text { Graduate Assistants/ } \\
\text { Associates }\end{array}$ & & 1,621 & & 1,692 & & 1,694 & & 1,747 & & 1,835 \\
\hline $\begin{array}{c}\text { Executive/ } \\
\text { Administrative/ Managerial }\end{array}$ & 443 & 12 & 463 & 16 & 517 & 15 & 527 & 15 & 554 & 17 \\
\hline Other Professional & 1,662 & 83 & 1,687 & 95 & 1,593 & 85 & 1,587 & 68 & 1,613 & 79 \\
\hline Non-Professional & 1,508 & 29 & 1,538 & 31 & 1,618 & 41 & 1,580 & 36 & 1,573 & 60 \\
\hline TOTAL PERSONNEL & $7,($ & & 7,3 & & & & & & & \\
\hline
\end{tabular}

*Due to a programming concern, part-time calculations are currently being reviewed. Changes would be applicable to both this report and IPEDS HR survey submission. In turn, campus-level figures will not roll-up to sum to these total USF numbers. 
STATE UNIVERSITY SYSTEM - 2010 ANNUAL REPORT

Section 3 - Enrollment \& Space

University of South Florida--Tampa

Table 3A. University Full-Time Enrollment (FTE)

\begin{tabular}{|c|c|c|c|c|c|c|}
\hline & \multicolumn{2}{|c|}{ 2008-09 } & \multicolumn{2}{|c|}{ 2009-10 } & \multicolumn{2}{|c|}{ 2010-11 } \\
\hline & Funded & Actual & Funded & Actual & Funded & Estimated \\
\hline \multicolumn{7}{|l|}{ Florida Residents } \\
\hline Lower & 8,783 & 8,231 & 8,617 & 7,928 & 8,617 & 8,088 \\
\hline Upper & 10,117 & 10,680 & 9,999 & 10,190 & 9,999 & 10,536 \\
\hline Grad I & 3,018 & 3,405 & 2,672 & 2,554 & 2,672 & 2,605 \\
\hline Grad II & 854 & 854 & 623 & 716 & 623 & 752 \\
\hline Total & 22,772 & 23,170 & 21,911 & 21,389 & 21,911 & 21,981 \\
\hline \multicolumn{7}{|l|}{ Non-Residents } \\
\hline Lower & & 316 & & 306 & & 321 \\
\hline Upper & & 366 & & 326 & & 342 \\
\hline Grad I & & 366 & & 350 & & 378 \\
\hline Grad II & & 232 & & 236 & & 250 \\
\hline Total & & 1,280 & & 1,218 & & 1,292 \\
\hline \multicolumn{7}{|l|}{ Total FTE } \\
\hline Lower & & 8,546 & & 8,234 & & 8,409 \\
\hline Upper & & 11,046 & & 10,516 & & 10,878 \\
\hline Grad I & & 3,771 & & 2,904 & & 2,983 \\
\hline Grad II & & 1,087 & & 952 & & 1,002 \\
\hline $\begin{array}{c}\text { Total FTE } \\
\text { (FL Definition) }\end{array}$ & 24,069 & 24,450 & 23,208 & 22,607 & 23,208 & 23,272 \\
\hline $\begin{array}{c}\text { Total FTE } \\
\text { (US Definition) }\end{array}$ & 32,092 & 32,579 & 32,092 & 33,473 & 32,092 & 34,200 \\
\hline \multicolumn{7}{|c|}{ Student Headcount in Medical Doctorate (Medicine, Dentistry, Veterinary) Programs } \\
\hline & \multicolumn{2}{|c|}{ 2008-09 } & \multicolumn{2}{|c|}{$2009-10$} & \multicolumn{2}{|c|}{$2010-11$} \\
\hline & Funded & Actual & Funded & Actual & Funded & Estimated \\
\hline Florida Residents & 480 & 465 & 480 & 480 & 480 & 460 \\
\hline Non-Residents & 0 & 17 & 0 & 0 & 0 & 22 \\
\hline Total & 480 & 482 & 480 & 480 & 480 & 480 \\
\hline $\begin{array}{l}\text { Notes: Florida definit } \\
\text { are used for all items } \\
\text { an Undergraduate FT } \\
\text { Fall enrollment data. }\end{array}$ & ff FTE (Ur & $\begin{array}{l}\text { raduate } \\
\text { ed Total } \\
\text { e FTE }=2\end{array}$ & $\begin{array}{l}=40 \text { and } \\
\text { (US Defin } \\
\text { edit hours }\end{array}$ & $\begin{array}{l}\text { duate FTH } \\
\text { n), which }\end{array}$ & 32 credit h & $\begin{array}{l}\text { rs per FTE) } \\
\text { are based on }\end{array}$ \\
\hline
\end{tabular}




\begin{tabular}{|c|c|c|c|}
\hline \multicolumn{4}{|c|}{$\begin{array}{l}\text { STATE UNIVERSITY SYSTEM - } 2010 \text { ANNUAL REPORT } \\
\text { Section } 3 \text { - Enrollment \& Space }\end{array}$} \\
\hline \multicolumn{4}{|c|}{ University of South Florida--Tampa } \\
\hline \multicolumn{4}{|c|}{ Table 3B. Enrollment by Location } \\
\hline \multicolumn{4}{|c|}{$\begin{array}{l}\text { For each distinct location (main, branch, site, regional campus) with> } 150 \text { FTE. } \\
\text { Add additional tables for sites, as needed. }\end{array}$} \\
\hline \multicolumn{4}{|c|}{ SITE: USF - Tampa/Main } \\
\hline FTE by LEVEL & $\begin{array}{l}\text { 2008-09 } \\
\text { Actual }\end{array}$ & $\begin{array}{l}\text { 2009-10 } \\
\text { Actual }\end{array}$ & $\begin{array}{c}2010-11 \\
\text { Estimated }\end{array}$ \\
\hline Lower & 8,546 & 8,234 & 8,409 \\
\hline Upper & 11,046 & 10,516 & 10,878 \\
\hline Grad I & 3,771 & 2,904 & 2,983 \\
\hline Grad II & 1,087 & 952 & 1,002 \\
\hline Total & 24,450 & 22,607 & 23,272 \\
\hline \multicolumn{4}{|l|}{ SITE: USF/Health } \\
\hline FTE by LEVEL & $\begin{array}{l}\text { 2008-09 } \\
\text { Actual }\end{array}$ & $\begin{array}{r}2009-10 \\
\text { Actual }\end{array}$ & $\begin{array}{c}\text { 2010-11 } \\
\text { Estimated }\end{array}$ \\
\hline Lower & 316 & 349 & 319 \\
\hline Upper & 844 & 875 & 854 \\
\hline Grad I & 978 & 1,045 & 985 \\
\hline Grad II & 209 & 206 & 220 \\
\hline Total & 2,347 & 2,475 & 2,378 \\
\hline
\end{tabular}


STATE UNIVERSITY SYSTEM - 2010 ANNUAL REPORT

Section 4 - Undergraduate Education

University of South Florida--Tampa

Table 4A. Baccalaureate Degree Program Changes in AY 2009-2010

\begin{tabular}{|c|c|c|c|c|c|}
\hline $\begin{array}{c}\text { Title of Program } \\
\text { (add more rows as needed) }\end{array}$ & $\begin{array}{c}\text { Six-digit } \\
\text { CIP Code }\end{array}$ & $\begin{array}{c}\text { Degree } \\
\text { Level }\end{array}$ & $\begin{array}{c}\text { Date of } \\
\text { UBOT } \\
\text { Action }\end{array}$ & $\begin{array}{c}\text { Starting } \\
\text { or Ending } \\
\text { Term }\end{array}$ & Comments \\
\hline New Programs & 52.1499 & BA, BS & $12 / 3 / 2009$ & Fall 2010 & USF \\
\hline Advertising & & & & \\
\hline
\end{tabular}

Terminated Programs

\begin{tabular}{|l|l|l|l|l|l|}
\hline N/A & & & & & \\
\hline & & & & & \\
\hline
\end{tabular}

Suspended Programs

\begin{tabular}{|l|l|l|l|l|l|}
\hline N/A & & & & & \\
\hline & & & & & \\
\hline
\end{tabular}

New Programs Considered by University But Not Approved 


\begin{tabular}{|c|c|c|c|c|c|}
\hline \multicolumn{5}{|c|}{$\begin{array}{c}\text { STATE UNIVERSITY SYSTEM - 2010 ANNUAL REPORT } \\
\text { Section 4 - Undergraduate Education }\end{array}$} \\
\hline \multicolumn{5}{|c|}{ University of South Florida--Tampa } \\
\hline Table 4B. First-Year Persistence Rates \\
\hline $\begin{array}{c}\text { Term of Entry } \\
\text { Cohort Size } \\
\text { Full-Time FTIC }\end{array}$ & 2004 & 2005 & 2006 & 2007 & 2008 \\
\hline From Same University & 4,399 & 4,170 & 4,125 & 3,853 & 3,930 \\
\hline \% Still Enrolled & $83 \%$ & $82 \%$ & $83 \%$ & $86 \%$ & $86 \%$ \\
\hline
\end{tabular}

\begin{tabular}{|c|c|c|c|c|c|}
\hline Term of Entry & Fall 2000 & Fall 2001 & Fall 2002 & Fall 2003 & Fall 2004 \\
\hline $\begin{array}{l}\text { Cohort Size } \\
\text { Full-Time FTIC }\end{array}$ & \multicolumn{5}{|c|}{$\begin{array}{c}\text { Parsing of retention/graduation data at the campus-level cannot be completed at } \\
\text { this time. }\end{array}$} \\
\hline \multicolumn{6}{|l|}{6 - Year Rates } \\
\hline \multicolumn{6}{|c|}{ From Same University } \\
\hline$\%$ Graduated & \multirow{2}{*}{\multicolumn{5}{|c|}{$\begin{array}{l}\text { Parsing of retention/graduation data at the campus-level cannot be completed at } \\
\text { this time. }\end{array}$}} \\
\hline \% Still Enrolled & & & & & \\
\hline \multicolumn{6}{|l|}{ Success Rate } \\
\hline $\begin{array}{l}\text { Notes: (1) Cohorts are } \\
\text { term and continue into } \\
\text { who have either gradu }\end{array}$ & $\begin{array}{l}\text { on undergradu } \\
11 \text { term); (2) Su } \\
\text { are still enrol }\end{array}$ & $\begin{array}{l}\text { students wh } \\
\text { ss Rate meast }\end{array}$ & $\begin{array}{l}\text { ter the instit } \\
\text { the percent }\end{array}$ & $\begin{array}{l}\mathrm{n} \text { in the Fall } \\
\text { of an intial co }\end{array}$ & $\begin{array}{l}\text { (or Summer } \\
\text { t of students }\end{array}$ \\
\hline
\end{tabular}




\section{STATE UNIVERSITY SYSTEM - 2010 ANNUAL REPORT \\ Section 4 - Undergraduate Education Data \\ University of South Florida--Tampa}

Table 4D. SUS - Undergraduate Progression and Graduation Rates

for First-Time-in-College (FTIC) Students

\begin{tabular}{|c|c|c|c|c|c|}
\hline Term of Entry & Fall 2000 & Fall 2001 & Fall 2002 & Fall 2003 & Fall 2004 \\
\hline $\begin{array}{l}\text { Cohort Size } \\
\text { Full- E Part-Time }\end{array}$ & \multicolumn{5}{|c|}{$\begin{array}{l}\text { Parsing of retention/graduation data at the campus-level cannot be completed at } \\
\text { this time. }\end{array}$} \\
\hline \multicolumn{6}{|l|}{4 - Year Rates } \\
\hline \multicolumn{6}{|c|}{ From Same University } \\
\hline$\%$ Graduated & \multirow{2}{*}{\multicolumn{5}{|c|}{$\begin{array}{l}\text { Parsing of retention/graduation data at the campus-level cannot be completed at } \\
\text { this time. }\end{array}$}} \\
\hline \% Still Enrolled & & & & & \\
\hline \multicolumn{6}{|c|}{ From Other SUS Institution } \\
\hline$\%$ Graduated & \multirow{2}{*}{\multicolumn{5}{|c|}{$\begin{array}{l}\text { Parsing of retention/graduation data at the campus-level cannot be completed at } \\
\text { this time. }\end{array}$}} \\
\hline \% Still Enrolled & & & & & \\
\hline \multicolumn{6}{|c|}{ From State University System } \\
\hline$\%$ Graduated & \multirow{3}{*}{\multicolumn{5}{|c|}{$\begin{array}{c}\text { Parsing of retention/graduation data at the campus-level cannot be completed at } \\
\text { this time. }\end{array}$}} \\
\hline$\%$ Still Enrolled & & & & & \\
\hline Success Rate & & & & & \\
\hline \multicolumn{6}{|l|}{6 - Year Rates } \\
\hline \multicolumn{6}{|c|}{ From Same University } \\
\hline$\%$ Graduated & \multirow{2}{*}{\multicolumn{5}{|c|}{$\begin{array}{l}\text { Parsing of retention/graduation data at the campus-level cannot be completed at } \\
\text { this time. }\end{array}$}} \\
\hline$\%$ Still Enrolled & & & & & \\
\hline \multicolumn{6}{|c|}{ From Other SUS Institution } \\
\hline$\%$ Graduated & \multirow{2}{*}{\multicolumn{5}{|c|}{$\begin{array}{l}\text { Parsing of retention/graduation data at the campus-level cannot be completed at } \\
\text { this time. }\end{array}$}} \\
\hline \% Still Enrolled & & & & & \\
\hline \multicolumn{6}{|c|}{ From State University System } \\
\hline$\%$ Graduated & \multirow{3}{*}{\multicolumn{5}{|c|}{$\begin{array}{l}\text { Parsing of retention/graduation data at the campus-level cannot be completed at } \\
\text { this time. }\end{array}$}} \\
\hline \% Still Enrolled & & & & & \\
\hline Success Rate & & & & & \\
\hline \multicolumn{6}{|c|}{$\begin{array}{l}\text { Notes: (1) Cohorts are based on undergraduate students who enter the institution in the Fall term (or Summer } \\
\text { term and continue into the Fall term); (2) Success Rate measures the percentage of an intial cohort of students } \\
\text { who have either graduated or are still enrolled. }\end{array}$} \\
\hline
\end{tabular}




\section{STATE UNIVERSITY SYSTEM - 2010 ANNUAL REPORT \\ Section 4 - Undergraduate Education Data \\ University of South Florida--Tampa}

\section{Table 4E. SUS - Undergraduate Progression and Graduation Rates}

for AA Transfer Students

\begin{tabular}{|c|c|c|c|c|c|}
\hline Term of Entry & Fall 2002 & Fall 2003 & Fall 2004 & Fall 2005 & Fall 2006 \\
\hline $\begin{array}{c}\text { Cohort Size } \\
\text { Full- E Part-Time }\end{array}$ & Parsing of retention/graduation data at the campus-level cannot be completed at \\
this time.
\end{tabular}

\section{2 - Year Rates}

\section{From Same University}

$\%$ Graduated

$\%$ Still Enrolled

Parsing of retention/graduation data at the campus-level cannot be completed at this time.

\section{From Other SUS Institution}

\begin{tabular}{|c|l|}
\hline \% Graduated & Parsing of retention/graduation data at the campus-level cannot be completed at \\
this time.
\end{tabular}

\section{4 - Year Rates}

\section{From Same University}

\begin{tabular}{|c|c|}
\hline$\%$ Graduated & Parsing of retention/graduation data at the campus-level cannot be completed at \\
this time.
\end{tabular}

\section{From Other SUS Institution}

$\%$ Graduated

$\%$ Still Enrolled
Parsing of retention/graduation data at the campus-level cannot be completed at this time.

\section{From State University System}

$\%$ Graduated

$\%$ Still Enrolled

Success Rate
Parsing of retention/graduation data at the campus-level cannot be completed at this time.

Notes: (1) Cohorts are based on undergraduate students who enter the institution in the Fall term (or Summer term and continue into the Fall term); (2) Success Rate measures the percentage of an intial cohort of students who have either graduated or are still enrolled. 


\section{STATE UNIVERSITY SYSTEM - 2010 ANNUAL REPORT \\ Section 4 - Undergraduate Education Data \\ University of South Florida--Tampa}

\section{Table 4F. SUS - Undergraduate Progression and Graduation Rates}

for Other Transfer Students

\begin{tabular}{|c|c|c|c|c|c|}
\hline Term of Entry & Fall 2001 & Fall 2002 & Fall 2003 & Fall 2004 & Fall 2005 \\
\hline $\begin{array}{l}\text { Cohort Size } \\
\text { Full- E Part-Time }\end{array}$ & \multicolumn{5}{|c|}{$\begin{array}{c}\text { Parsing of retention/graduation data at the campus-level cannot be completed at } \\
\text { this time. }\end{array}$} \\
\hline \multicolumn{6}{|l|}{5 - Year Rates } \\
\hline \multicolumn{6}{|c|}{ From Same University } \\
\hline$\%$ Graduated & \multirow{2}{*}{\multicolumn{5}{|c|}{$\begin{array}{l}\text { Parsing of retention/graduation data at the campus-level cannot be completed at } \\
\text { this time. }\end{array}$}} \\
\hline \% Still Enrolled & & & & & \\
\hline \multicolumn{6}{|c|}{ From Other SUS Institution } \\
\hline$\%$ Graduated & \multirow{2}{*}{\multicolumn{5}{|c|}{$\begin{array}{l}\text { Parsing of retention/graduation data at the campus-level cannot be completed at } \\
\text { this time. }\end{array}$}} \\
\hline \% Still Enrolled & & & & & \\
\hline \multicolumn{6}{|c|}{ From State University System } \\
\hline$\%$ Graduated & \multirow{3}{*}{\multicolumn{5}{|c|}{$\begin{array}{l}\text { Parsing of retention/graduation data at the campus-level cannot be completed at } \\
\text { this time. }\end{array}$}} \\
\hline$\%$ Still Enrolled & & & & & \\
\hline Success Rate & & & & & \\
\hline \multicolumn{6}{|c|}{$\begin{array}{l}\text { Notes: (1) Cohorts are based on undergraduate students who enter the institution in the Fall term (or Summer } \\
\text { term and continue into the Fall term); (2) Success Rate measures the percentage of an intial cohort of students } \\
\text { who have either graduated or are still enrolled. }\end{array}$} \\
\hline
\end{tabular}

\section{Table 4G. Baccalaureate Degrees Awarded}

\begin{tabular}{|l|c|c|c|c|c|}
\hline & $2005-2006$ & $2006-2007$ & $2007-2008$ & $2008-2009$ & $2009-2010$ \\
\hline Baccalaureate Degrees & 4,935 & 5,479 & 5,758 & 6,073 & 6,599 \\
\hline
\end{tabular}

\section{Table 4H. Baccalaureate Degrees Awarded in Areas of Strategic Emphasis}

\begin{tabular}{|c|c|c|c|c|c|}
\hline & $\mathbf{2 0 0 5 - 2 0 0 6}$ & $\mathbf{2 0 0 6 - 2 0 0 7}$ & $\mathbf{2 0 0 7 - 2 0 0 8}$ & $\mathbf{2 0 0 8 - 2 0 0 9}$ & $\mathbf{2 0 0 9 - 2 0 1 0}$ \\
\hline Education & 78 & 74 & 83 & 86 & 91 \\
\hline Health Professions & 338 & 435 & 401 & 414 & 432 \\
\hline $\begin{array}{c}\text { Science, Technology, } \\
\text { Engineering, and Math }\end{array}$ & 1,049 & 1,199 & 1,231 & 1,324 & 1,472 \\
\hline $\begin{array}{c}\text { Security and } \\
\text { Emergency Services }\end{array}$ & 243 & 295 & 318 & 325 & 358 \\
\hline $\begin{array}{c}\text { Globalization } \\
\text { TOTAL: Areas of } \\
\text { Strategic Emphasis }\end{array}$ & $\mathbf{2 , 0 5 0}$ & $\mathbf{2 , 3 9 3}$ & $\mathbf{2 , 4 3 7}$ & $\mathbf{2 , 5 8 1}$ & $\mathbf{2 , 8 0 7}$ \\
\hline
\end{tabular}




\section{STATE UNIVERSITY SYSTEM - 2010 ANNUAL REPORT \\ Section 4 - Undergraduate Education Data \\ University of South Florida--Tampa}

\section{Table 4I. Baccalaureate Degrees Awarded to Underrepresented Groups}

\begin{tabular}{|c|c|c|c|c|c|}
\hline & 2005-2006 & 2006-2007 & 2007-2008 & $\begin{array}{c}2008-2009 \\
\text { BASELINE YEAR }\end{array}$ & 2009-2010 \\
\hline \multicolumn{6}{|c|}{ Non-Hispanic Black Students } \\
\hline $\begin{array}{c}\text { Number of } \\
\text { Baccalaureate Degrees }\end{array}$ & 613 & 686 & 723 & $\begin{array}{c}786 \\
\text { Increase* }\end{array}$ & 795 \\
\hline $\begin{array}{c}\text { Percentage of All } \\
\text { Baccalaureate Degrees }\end{array}$ & $13.1 \%$ & $13.1 \%$ & $13.2 \%$ & $\begin{array}{c}13.5 \% \\
\text { Increase* }\end{array}$ & $12.5 \%$ \\
\hline \multicolumn{6}{|l|}{ Hispanic Students } \\
\hline $\begin{array}{c}\text { Number of } \\
\text { Baccalaureate Degrees }\end{array}$ & 511 & 620 & 657 & $\begin{array}{c}759 \\
\text { Increase* }\end{array}$ & 830 \\
\hline $\begin{array}{c}\text { Percentage of All } \\
\text { Baccalaureate Degrees }\end{array}$ & $10.9 \%$ & $11.8 \%$ & $12.0 \%$ & $\begin{array}{c}13 \% \\
\text { Increase* }^{*}\end{array}$ & $13.0 \%$ \\
\hline \multicolumn{6}{|l|}{ PELL-Grant Recipients } \\
\hline $\begin{array}{c}\text { Number of } \\
\text { Baccalaureate Degrees* }\end{array}$ & 2,003 & 2,083 & 2,193 & $\begin{array}{c}2260 \\
\text { Maintain* }\end{array}$ & 2,679 \\
\hline $\begin{array}{c}\text { Percentage of All } \\
\text { Baccalaureate Degrees }\end{array}$ & $43 \%$ & $40 \%$ & $40 \%$ & $\begin{array}{c}38.8 \% \\
\text { Maintain* }\end{array}$ & $41 \%$ \\
\hline \multicolumn{6}{|c|}{$\begin{array}{l}\text { Note: PELL-Grant recipients are defined as those students who have received a PELL-Grant Within } 6 \text { Years of } \\
\text { Graduation. This does not include degrees awarded to students whose race/ethnicity code is missing (or not reported) o } \\
\text { for students who are non-resident aliens. Note*: Directional goals for the 2012-13 year as reported in the } 2010 \text { University } \\
\text { Workplan. }\end{array}$} \\
\hline
\end{tabular}

*Due to methodology changes in this data metric, campus-level figures may not roll up to the system numbers.

\begin{tabular}{|c|c|c|c|c|c|}
\hline & 2005-2006 & 2006-2007 & $2007-2008$ & 2008-2009 & $2009-2010$ \\
\hline $\begin{array}{c}\text { \% of Total Baccalaureate } \\
\text { Degrees Awarded Within } \\
110 \% \text { of Hours Required } \\
\text { for Degree }\end{array}$ & $\%$ & $\%$ & $34.5 \%$ & $35.1 \%$ & $34.6 \%$ \\
\hline
\end{tabular}

\section{Table 4K. Undergraduate Course Offerings}

\begin{tabular}{c|c|c|c|c|c} 
& Fall 2005 & Fall 2006 & Fall 2007 & Fall 2008 & Fall 2009 \\
$\begin{array}{c}\text { Number of } \\
\text { Course Sections }\end{array}$ & 2,399 & 2,443 & 2,597 & 2,453 & 2,591 \\
\hline
\end{tabular}

Percentage of Undergraduate Course Sections by Class Size

\begin{tabular}{|c|c|c|c|c|c|}
\hline $\begin{array}{c}\text { Fewer than } 30 \\
\text { Students }\end{array}$ & $53.6 \%$ & $55.1 \%$ & $58.1 \%$ & $55.2 \%$ & $57.5 \%$ \\
\hline $\begin{array}{c}30 \text { to } 49 \\
\text { Students }\end{array}$ & $28.8 \%$ & $28.5 \%$ & $26.3 \%$ & $27.7 \%$ & $27.1 \%$ \\
\hline $\begin{array}{c}50 \text { to } 99 \\
\text { Students }\end{array}$ & $13.2 \%$ & $12.2 \%$ & $11.6 \%$ & $13.2 \%$ & $11.8 \%$ \\
\hline $\begin{array}{c}\text { 100 or More } \\
\text { Students }\end{array}$ & $4.4 \%$ & $4.2 \%$ & $4.0 \%$ & $3.9 \%$ & $3.6 \%$ \\
\hline
\end{tabular}




\begin{tabular}{|c|c|c|c|c|c|}
\hline \multicolumn{6}{|c|}{$\begin{array}{l}\text { STATE UNIVERSITY SYSTEM - } 2010 \text { ANNUAL REPORT } \\
\text { Section } 4 \text { - Undergraduate Education Data }\end{array}$} \\
\hline \multicolumn{6}{|c|}{ University of South Florida--Tampa } \\
\hline Table 4L. Faculty Te & ig Underg & dates & & & \\
\hline & $2005-2006$ & 2006-2007 & 2007-2008 & 2008-2009 & 2009-2010 \\
\hline \multicolumn{6}{|c|}{ Percentage of Credit Hours Taught by: } \\
\hline Faculty & $61.7 \%$ & $61.3 \%$ & $61.1 \%$ & $63.1 \%$ & $65.4 \%$ \\
\hline Adjunct Faculty & $22.7 \%$ & $21.6 \%$ & $21.6 \%$ & $19.8 \%$ & $17.9 \%$ \\
\hline Graduate Students & $15.2 \%$ & $16.6 \%$ & $16.9 \%$ & $16.5 \%$ & $15.6 \%$ \\
\hline Other Instructors & $0.4 \%$ & $0.5 \%$ & $0.5 \%$ & $0.6 \%$ & $1.1 \%$ \\
\hline
\end{tabular}

\begin{tabular}{|} 
Table 4M. Undergraduate Instructional Faculty Compensation \\
\hline & Fall 2005 & Fall 2006 & Fall 2007 & Fall 2008 & Fall 2009 \\
\hline $\begin{array}{c}\text { Average Salary and } \\
\text { Benefits for Faculty Who } \\
\text { Teach at Least One } \\
\text { Undergraduate Course }\end{array}$ & $\$ 80,414$ & $\$ 82,840$ & $\$ 86,795$ & $\$ 89,571$ & $\$ 93,013$ \\
\hline
\end{tabular}

\section{Table 4N. Student/Faculty Ratio}

\begin{tabular}{|l|c|c|c|c|c|}
\hline & $2005-2006$ & $2006-2007$ & $2007-2008$ & $2008-2009$ & $2009-2010$ \\
\hline Student-to-Faculty Ratio & 27 & 27 & 28 & 28 & 27 \\
\hline
\end{tabular}

Note: The definition of faculty varies for Tables $4 \mathrm{~L}, 4 \mathrm{M}$ and $4 \mathrm{~N}$. For Student/Faculty Ratio, the definition of faculty is consistent with Common Data Set reporting (which counts full-time equivalent instructional faculty as full-time faculty plus $1 / 3$ part-time faculty). 


\section{STATE UNIVERSITY SYSTEM - 2010 ANNUAL REPORT \\ Section 4 - Undergraduate Education Data}

University of South Florida--Tampa

\section{Table 4O. Professional Licensure Exams - Undergraduate Programs}

\begin{tabular}{|l|c|c|c|c|c|}
\hline & 2005 & 2006 & 2007 & 2008 & 2009 \\
\hline Nursing: National Council Licensure Examination for Registered Nurses & 157 & 151 \\
\hline Examinees & 121 & 95 & 152 & $98.1 \%$ & $96.0 \%$ \\
\hline Pass Rate & $95.9 \%$ & $82.1 \%$ & $92.1 \%$ & $87.5 \%$ & $89.5 \%$ \\
\hline National Benchmark & $86.7 \%$ & $88.3 \%$ & $86.4 \%$ & 8 \\
\hline
\end{tabular}

Note: All licensure data is based on first-time examinees.

\section{Table 4P. Tuition Differential Fee *}

\begin{tabular}{|c|c|c|c|}
\hline & 2008-2009 & 2009-2010 & $\begin{array}{l}\text { 2010-2011 } \\
\text { Projected }\end{array}$ \\
\hline $\begin{array}{l}\text { Total Revenues Generated } \\
\text { By the Tuition Differential }\end{array}$ & --- & $\$ 6,711,769$ & $\$ 12,364,253$ \\
\hline $\begin{array}{c}\text { Unduplicated Count of Students } \\
\text { Receiving Financial Aid Award } \\
\text { Funded by Tuition Differential Revenues }\end{array}$ & --- & 1,928 & \\
\hline $\begin{array}{c}\text { Average Amount of Awards } \\
\text { Funded by Tuition Differential Revenues } \\
\text { (per student receiving an award) }\end{array}$ & --- & $\$ 1,046$ & \\
\hline Number of Students Eligible for FSAG & -- & 6,038 & \\
\hline $\begin{array}{c}\text { Number of FSAG-Eligible Students Receiving } \\
\text { a Waiver of the Tuition Differential }\end{array}$ & & 0 & 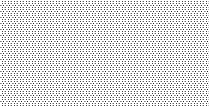 \\
\hline $\begin{array}{l}\text { Value of Tuition Differential Waivers } \\
\text { Provided to FSAG-Eligible Students }\end{array}$ & & 0 & $\sqrt{1+5}$ \\
\hline \multicolumn{4}{|c|}{$\begin{array}{l}\text { Report on the success of the tuition differential in achieving the articulated purpose. Include an update on any } \\
\text { performance measures that were specified in the Board of Governors-approved tuition differential proposal. }\end{array}$} \\
\hline \multicolumn{4}{|c|}{$\begin{array}{l}\text { Since differential tuition was first implemented in 2008, USF has focused its efforts on promoting student success. In the } \\
\text { 2009-2010 Academic Year, USF: } \\
\text { - Expanded the number of academic advisors by } 12.25 \text { as part of a larger effort to centralize and professionalize advising } \\
\text { services to boost retention and graduation rates. } \\
\text { - Reduced the student to advisor ratio in selected, high-need departments; the goal remains to reduce this ratio to } 330: 1 . \\
\text { - Continued progress on the implementation of a new and more effective student tracking system that guides more } \\
\text { students through the degree process and reduces time to degree } \\
\text { - Enhanced tutoring and learning services by centralizing services in a "Learning Commons" in the library. This } \\
\text { includes a writing center, mathematics center, and STEM Center. } \\
\text { These efforts have been moved forward and integrated into a university-wide Student Success initiative, launched in } \\
\text { November } 2009 \text { with the formation of a } 100 \text {-member Student Success Task Force. While each one of the above initiatives } \\
\text { constitutes an important component of any campaign to enhance student success rates, they are more effective and } \\
\text { therefore more likely to succeed if they form part of a comprehensive and coordinated effort that leverages all university } \\
\text { initiatives, including but not limited to residential education policies, academic support services, financial aid packaging, } \\
\text { physical improvements, academic withdrawal policies, and revisions to the curriculum. }\end{array}$} \\
\hline
\end{tabular}


*Note: Counts of students and the average amount of awards funded are derived from an early submission of the tuition differential proposal and does not reflect current. As such, it should be noted that while we approve these USF System figures based on the given reporting instance, however, the campus figures will not roll up to the match the system totals as the reporting instance differs.

Detailed expenditures of the revenues generated by the tuition differential will be captured in the Operating Budget submission each August. 
STATE UNIVERSITY SYSTEM - 2010 ANNUAL REPORT

Section 5 - Graduate Education Data

University of South Florida--Tampa

\section{Table 5A. GraduateDegree Programs Changes in AY 2009-2010}

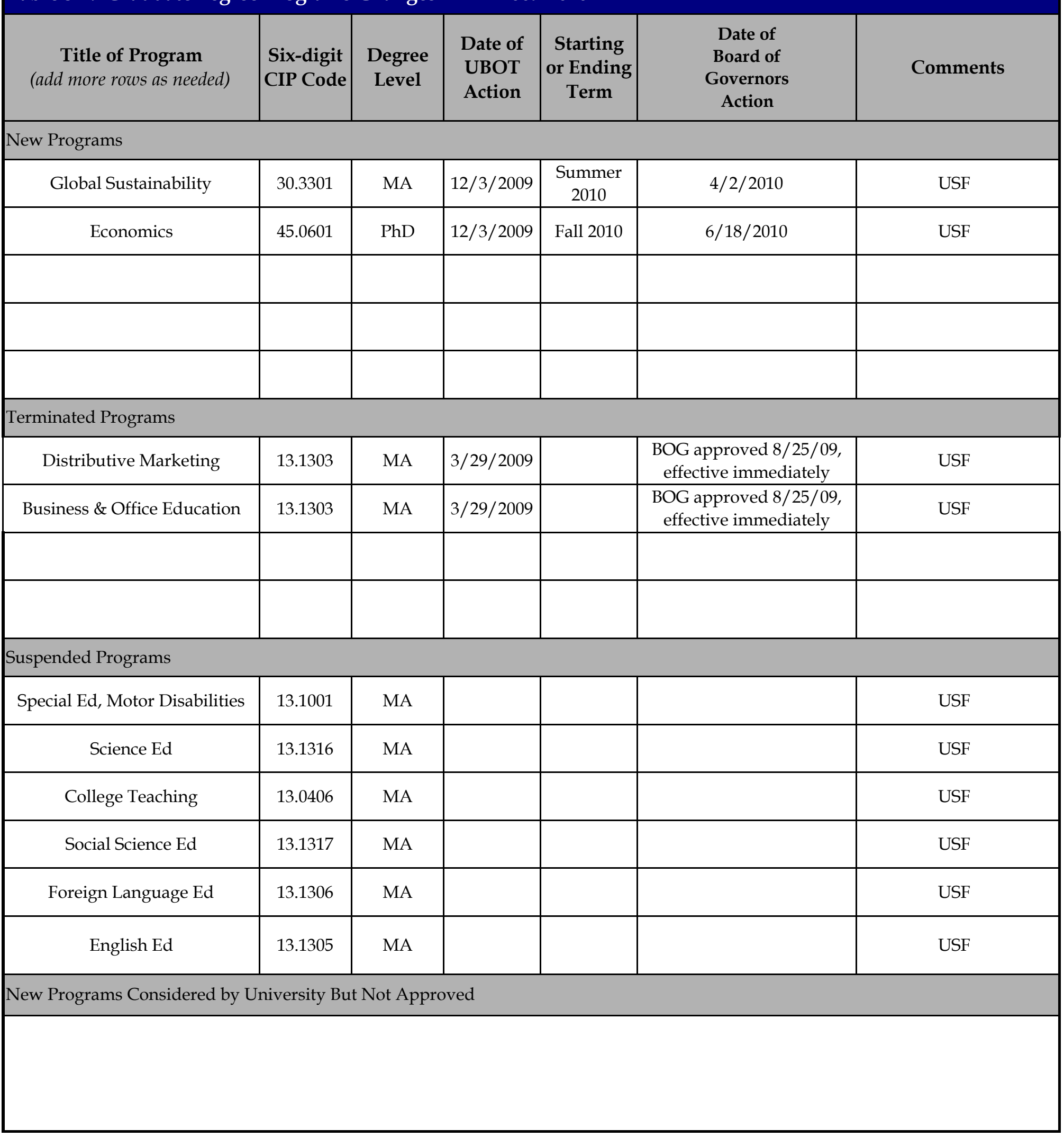


STATE UNIVERSITY SYSTEM - 2010 ANNUAL REPORT

Section 5 - Graduate Education Data

University of South Florida--Tampa

Table 5B. Graduate Degrees Awarded

\begin{tabular}{|c|c|c|c|c|c|}
\hline & 2005-2006 & 2006-2007 & $2007-2008$ & 2008-2009 & 2009-2010 \\
\hline Master's and Specialist & 1,737 & 1,803 & 2,014 & 2,096 & 2,259 \\
\hline Research Doctoral & 180 & 223 & 229 & 248 & 244 \\
\hline Professional Doctoral & 93 & 122 & 143 & 154 & 156 \\
\hline a) Medicine & 93 & 116 & 115 & 114 & 116 \\
\hline b) Law & 0 & 0 & 0 & 0 & 0 \\
\hline c) Pharmacy & 0 & 0 & 0 & 0 & 0 \\
\hline $\begin{array}{l}\text { Research/ Professional } \\
\text { Doctoral, Combined }\end{array}$ & 273 & 345 & 372 & 402 & 400 \\
\hline
\end{tabular}

Table 5C. Graduate Degrees Awarded in Areas of Strategic Emphasis

\begin{tabular}{|c|c|c|c|c|c|}
\hline & $\mathbf{2 0 0 5 - 2 0 0 6}$ & $\mathbf{2 0 0 6 - 2 0 0 7}$ & $\mathbf{2 0 0 7 - 2 0 0 8}$ & $\mathbf{2 0 0 8 - 2 0 0 9}$ & $\mathbf{2 0 0 9 - 2 0 1 0}$ \\
\hline $\begin{array}{c}\text { Education } \\
\text { Critical Shortage Areas }\end{array}$ & 88 & 116 & 112 & 140 & 129 \\
\hline Health Professions & 384 & 426 & 420 & 497 & 562 \\
\hline $\begin{array}{c}\text { Science, Technology, } \\
\text { Engineering, and Math }\end{array}$ & 426 & 453 & 543 & 529 & 616 \\
\hline $\begin{array}{c}\text { Security and } \\
\text { Emergency Services }\end{array}$ & 13 & 6 & 23 & 50 & 36 \\
\hline $\begin{array}{c}\text { Globalization } \\
\text { TOTAL }\end{array}$ & $\mathbf{9 4 8}$ & $\mathbf{1 , 0 4 3}$ & $\mathbf{1 , 1 4 4}$ & $\mathbf{1 , 2 5 7}$ & $\mathbf{1 , 3 9 6}$ \\
\hline
\end{tabular}


STATE UNIVERSITY SYSTEM - 2010 ANNUAL REPORT

Section 5 - Graduate Education Data

University of South Florida--Tampa

Table 5D. Professional Licensure Exams - Graduate Programs

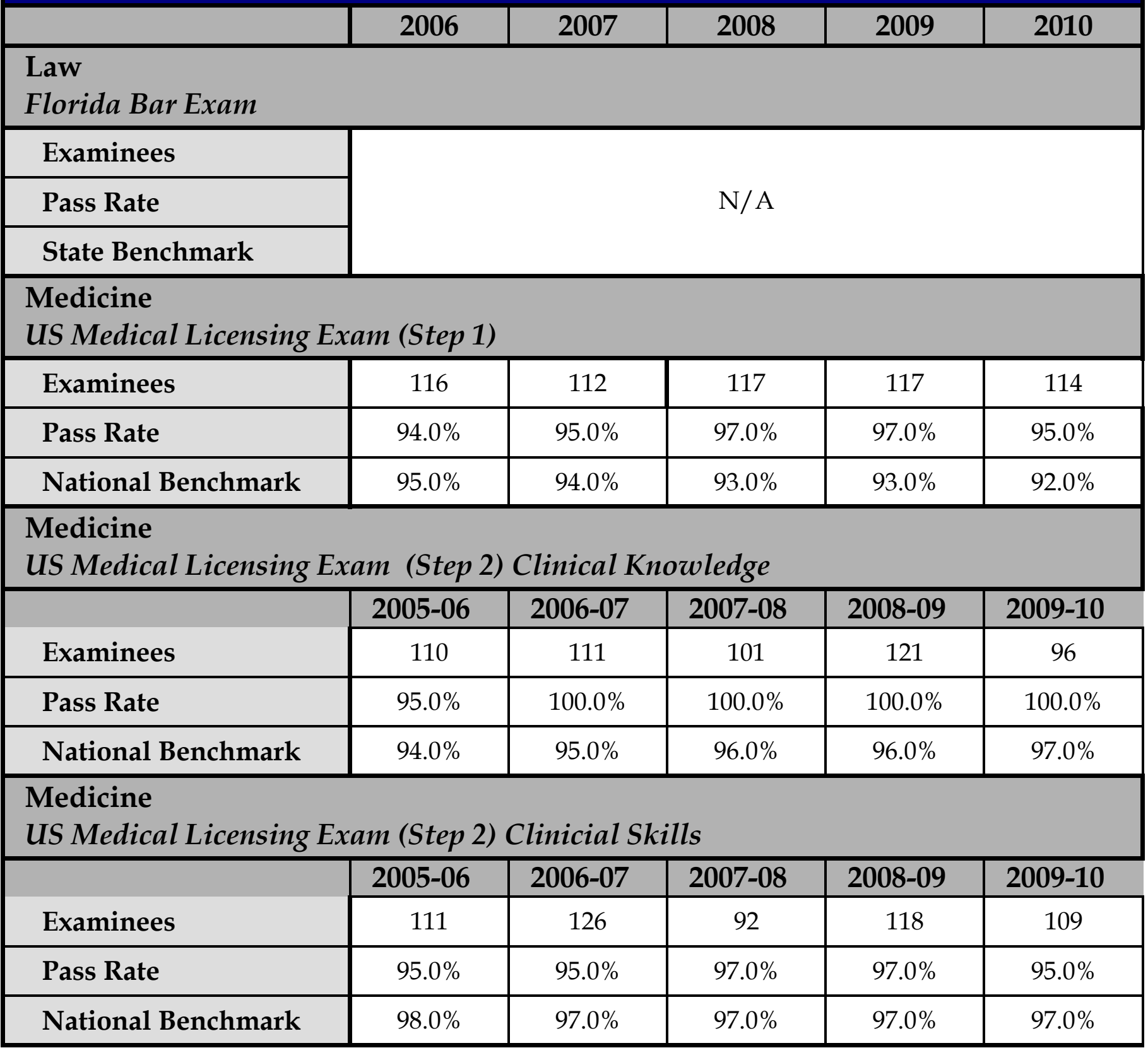

Note: All licensure data is based on first-time examinees. 
STATE UNIVERSITY SYSTEM - 2010 ANNUAL REPORT

Section 5 - Graduate Education Data

University of South Florida--Tampa

Table 5D. Professional Licensure Exams - Graduate Programs

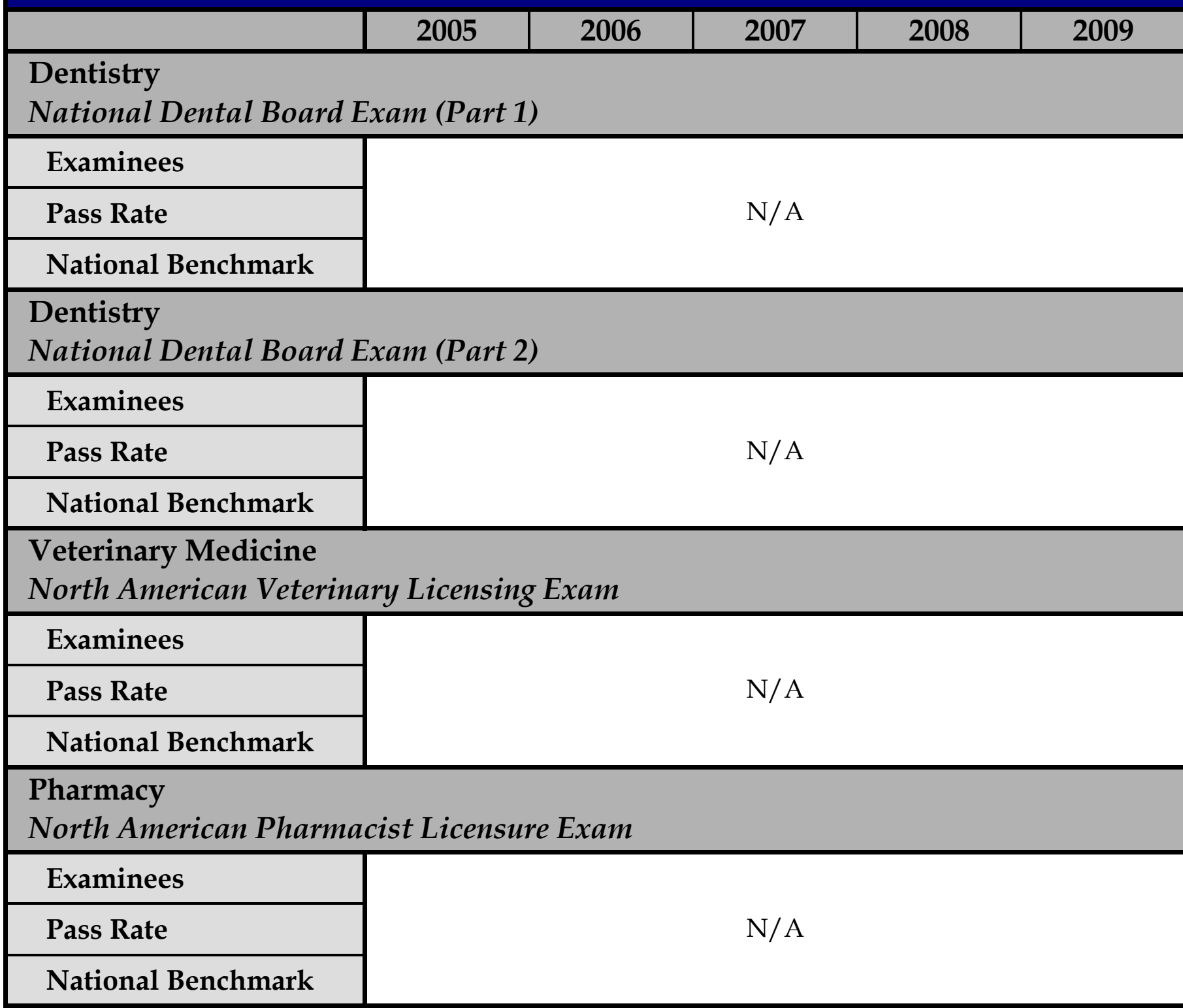

Note: All licensure data is based on first-time examinees. 


\begin{tabular}{|c|c|c|c|c|c|}
\hline \multicolumn{6}{|c|}{$\begin{array}{l}\text { STATE UNIVERSITY SYSTEM - } 2010 \text { ANNUAL REPORT } \\
\text { Section } 6 \text { - Research and Economic Development }\end{array}$} \\
\hline \multicolumn{6}{|c|}{ University of South Florida--Tampa } \\
\hline \multicolumn{6}{|c|}{ Table 6A. Research and Development } \\
\hline & 2004-2005 & 2005-2006 & 2006-2007 & 2007-2008 & 2008-2009 \\
\hline \multicolumn{6}{|c|}{ R\&D Awards (includes non-Science \& Engineering awards) } \\
\hline $\begin{array}{l}\text { Federally Funded Awards } \\
\text { (Thousand \$) }\end{array}$ & -- & -- & -- & -- & $\$ 187,301$ \\
\hline $\begin{array}{l}\text { Total Awards } \\
\text { (Thousand \$) }\end{array}$ & -- & -- & -- & -- & $\$ 281,613$ \\
\hline \multicolumn{6}{|c|}{ R\&D Expenditures (includes non-Science \& Engineering expenditures) } \\
\hline $\begin{array}{l}\text { Federally Financed Expenditures } \\
\text { (Thousand \$) }\end{array}$ & \multirow{3}{*}{\multicolumn{5}{|c|}{$\begin{array}{l}\text { Development/Research data is a USF system-wide function. Consolidated system } \\
\text { data is only available at this time. }\end{array}$}} \\
\hline $\begin{array}{l}\text { Total Expenditures } \\
\text { (Thousand \$) }\end{array}$ & & & & & \\
\hline $\begin{array}{l}\text { Total R\&D Expenditures } \\
\text { Per Full-Time, Tenured, } \\
\text { Tenure-Earning Faculty Member } \\
(\$)\end{array}$ & & & & & \\
\hline \multicolumn{6}{|c|}{ Technology Transfer (as reported to AUTM) } \\
\hline Invention Disclosures & 0 & 109 & 110 & 139 & 141 \\
\hline Total U.S. Patents Issued & 23 & 29 & 31 & 31 & 36 \\
\hline $\begin{array}{l}\text { Patents Issued Per 1,000 Full- } \\
\text { Time, Tenure and Tenure- } \\
\text { Earning Faculty }\end{array}$ & 20 & 24 & 26 & 26 & 28 \\
\hline $\begin{array}{l}\text { Total Number of Licenses/ } \\
\text { Options Executed }\end{array}$ & 20 & 21 & 23 & 28 & 25 \\
\hline $\begin{array}{l}\text { Total Licensing Income } \\
\text { Received (\$) }\end{array}$ & $\$ 1,548,818$ & $\$ 1,704,025$ & $\$ 2,099,712$ & $\$ 1,831,000$ & $\$ 1,300,000$ \\
\hline $\begin{array}{l}\text { Total Number of Start-Up } \\
\text { Companies }\end{array}$ & 6 & 6 & 4 & 5 & 3 \\
\hline
\end{tabular}




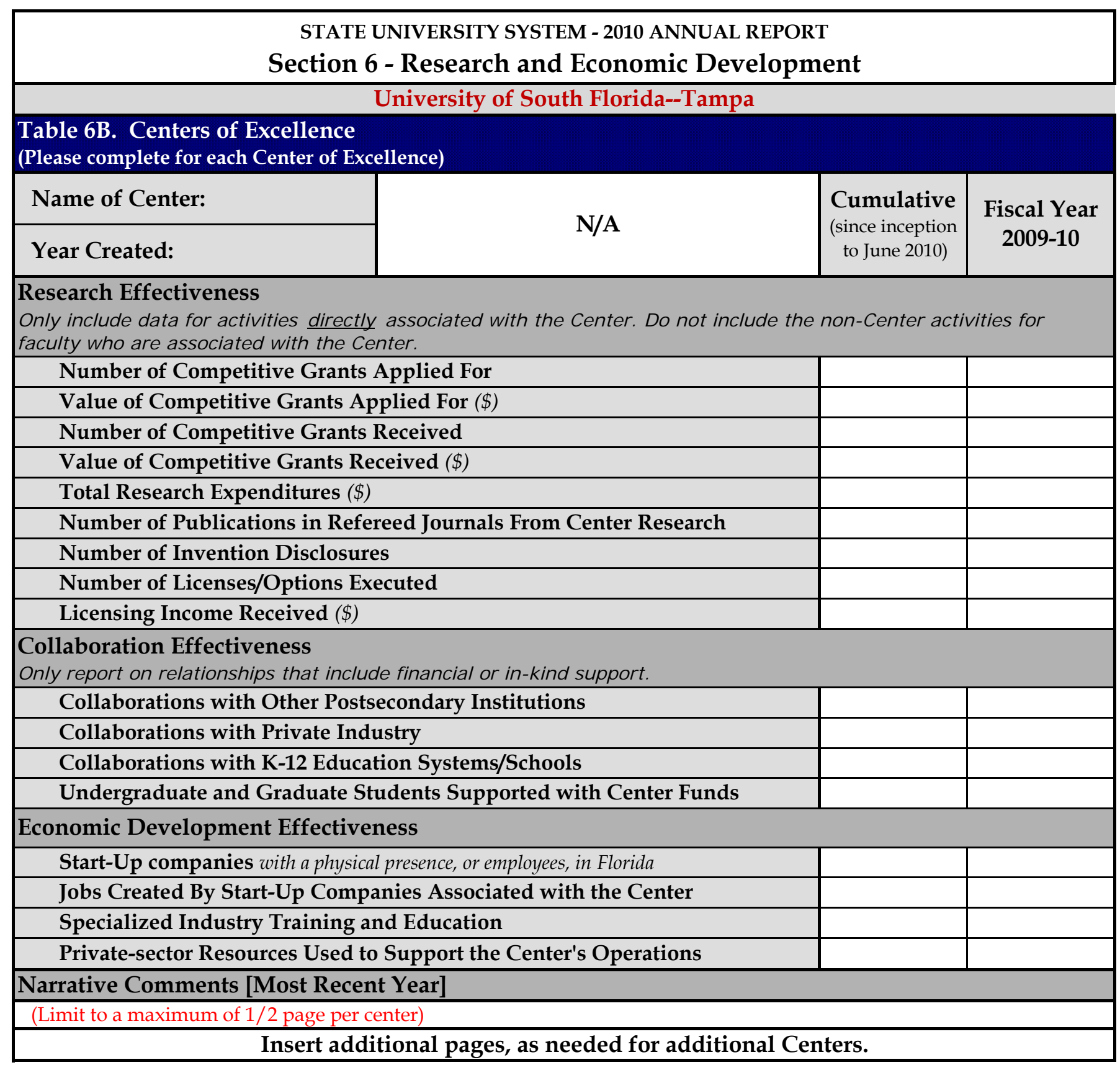




\begin{tabular}{|c|c|c|}
\hline \multicolumn{3}{|c|}{$\begin{array}{l}\text { STATE UNIVERSITY SYSTEM - } 2010 \text { ANNUAL REPORT } \\
\text { Section } 6 \text { - Research and Economic Development }\end{array}$} \\
\hline \multicolumn{3}{|c|}{ University of South Florida--Tampa } \\
\hline \multicolumn{3}{|c|}{ Table 6C. State University Research Commercialization Assistance Grants } \\
\hline \multirow{2}{*}{ Project Name by Type of Grant } & \multicolumn{2}{|c|}{ Cumulative } \\
\hline & AWARDS & EXPENDITURES \\
\hline \multicolumn{3}{|l|}{ Phase I Grants } \\
\hline \multirow[t]{2}{*}{ Early Stage RAID } & $\$ 50,000$ & $\$ 19,000$ \\
\hline & $\$ 0$ & $\$ 0$ \\
\hline \multicolumn{3}{|l|}{ Phase II Grants } \\
\hline \multirow[t]{2}{*}{ Platinum Compounds } & $\$ 50,000$ & $\$ 0$ \\
\hline & $\$ 0$ & $\$ 0$ \\
\hline \multicolumn{3}{|l|}{ Phase III Grants } \\
\hline & $\$ 0$ & $\$ 0$ \\
\hline Total for all SURCAG Grants & $\$ 100,000$ & $\$ 19,000$ \\
\hline \multicolumn{3}{|l|}{ Narrative Comments } \\
\hline \multicolumn{3}{|c|}{ 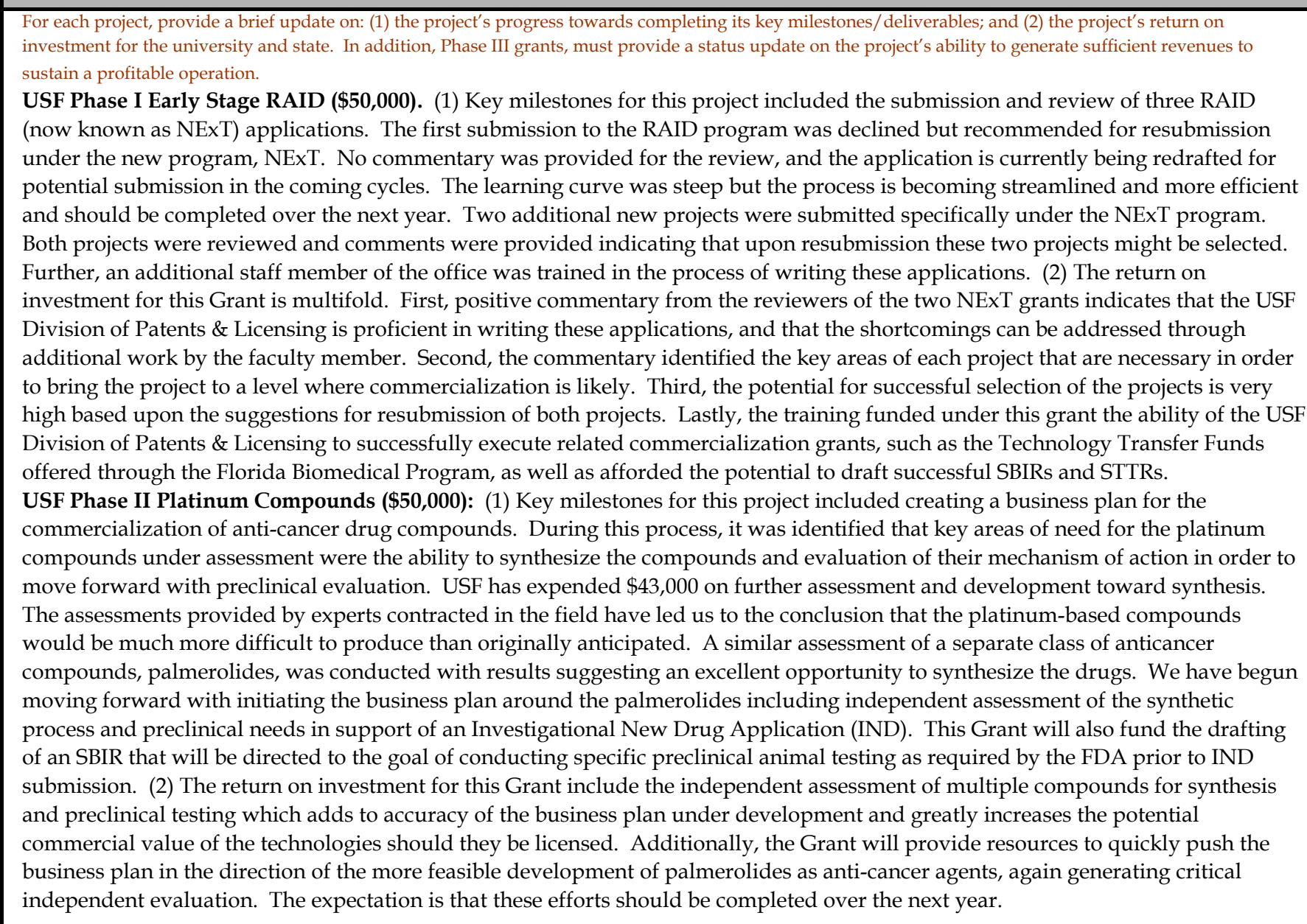 } \\
\hline
\end{tabular}




\section{University of South Florida--Tampa}

\section{Table 6D. 21st Century World Class Scholars Program}

\begin{tabular}{|c|c|c|c|c|c|}
\hline \multirow[b]{2}{*}{$\begin{array}{l}\text { World Class Scholar(s) } \\
\text { and Field }\end{array}$} & \multicolumn{2}{|c|}{ Grant Dollars } & \multicolumn{3}{|c|}{$\begin{array}{l}\text { Report the cumulative activity } \\
\text { since each scholar's award. }\end{array}$} \\
\hline & $\begin{array}{l}\text { Amount } \\
\text { Awarded } \\
\text { (Thousand \$) }\end{array}$ & $\begin{array}{l}\text { Cumulative } \\
\text { Amount } \\
\text { Expended } \\
\text { (Thousand \$) }\end{array}$ & $\begin{array}{l}\text { External } \\
\text { Research } \\
\text { Awards } \\
\text { (Thousand \$) }\end{array}$ & $\begin{array}{l}\text { Patents } \\
\text { Filed / } \\
\text { Issued }\end{array}$ & $\begin{array}{l}\text { Licensing } \\
\text { Revenues } \\
\text { Generated } \\
\quad(\$)\end{array}$ \\
\hline John Adams & 1,000 & 1,000 & $\$ 4,739$ & 0 & c \\
\hline Richard Gitlin & 1,000 & 1,000 & * & 2 filed & 0 \\
\hline James Mihelcic & 1,000 & 1,000 & $\$ 642$ & 0 & 0 \\
\hline Thomas Unnasch & 1,000 & 1,000 & $\$ 4,933$ & 1 filed & 0 \\
\hline TOTAL for all Scholars & $\$ 4,000$ & $\$ 4,000$ & $\$ 10,314$ & filed/0 issued & $\$ 0$ \\
\hline \multicolumn{6}{|c|}{ Narrative Comments } \\
\hline \multicolumn{6}{|c|}{$\begin{array}{l}\text { The grant dollars awarded per scholar reflect the initial award amount. All scholars have expended their total award } \\
\text { amount. } \\
\text { *Dr. Gitlin has submitted grant proposals totaling } \$ 548,230 \text {. }\end{array}$} \\
\hline
\end{tabular}

